\title{
A novel p53 rescue compound induces p53-dependent growth arrest and sensitises glioma cells to Apo2L/TRAIL-induced apoptosis
}

\author{
L Weinmann ${ }^{1,4}$, J Wischhusen ${ }^{\star, 1,2}$, MJ Demma ${ }^{3}$, U Naumann ${ }^{1}$, P Roth ${ }^{1}$, B DasMahapatra ${ }^{3}$ and M Weller ${ }^{1}$
}

Reactivation of mutant p53 in tumours is a promising strategy for cancer therapy. Here we characterise the novel p53 rescue compound P53R3 that restores sequence-specific DNA binding of the endogenously expressed $p 53^{\mathrm{R} 175 \mathrm{H}}$ and $\mathrm{p} 53^{\mathrm{R} 273 \mathrm{H}}$ mutants in gel-shift assays. Overexpression of the paradigmatic p53 mutants $p 53^{\mathrm{R} 175 \mathrm{H}}, \mathrm{p} 53^{\mathrm{R} 248 \mathrm{~W}}$ and $\mathrm{p} 53^{\mathrm{R} 273 \mathrm{H}}$ in the $\mathrm{p} 53$ null glioma cell line LN-308 reveals that P53R3 induces p53-dependent antiproliferative effects with much higher specificity and over a wider range of concentrations than the previously described p53 rescue drug p53 reactivation and induction of massive apoptosis (PRIMA-1). Furthermore, P53R3 enhances recruitment of endogenous $\mathrm{p} 53$ to several target promoters in glioma cells bearing mutant (T98G) and wild-type (LNT-229) p53 and induces mRNA expression of numerous p53 target genes in a p53-dependent manner. Interestingly, P53R3 strongly enhances the mRNA, total protein and cell surface expression of the death receptor death receptor 5 (DR5) whereas CD95 and TNF receptor 1 levels are unaffected. Accordingly, P53R3 does not sensitise for CD95 ligandor tumour necrosis factor $\alpha$-induced cell death, but displays synergy with Apo2L.0 in 9 of 12 glioma cell lines. Both DR5 surface induction and synergy with Apo2L.0 are sensitive to siRNA-mediated downregulation of p53. Thus this new p53 rescue compound may open up novel perspectives for the treatment of cancers currently considered resistant to the therapeutic induction of apoptosis.

Cell Death and Differentiation (2008) 15, 718-729; doi:10.1038/sj.cdd.4402301; published online 18 January 2008

The tumour suppressor protein p53 is a transcription factor that is mutationally inactivated in more than $50 \%$ of all human tumours. A pharmacologic reactivation of mutant $p 53$ by small molecules such as CP-31398 or PRIMA-1 (p53 reactivation and initiation of massive apoptosis-1) induces p53-dependent growth arrest and apoptosis and reduces tumour growth in mice. ${ }^{1,2}$ These compounds are thought to stabilise mutant p53 in a wild-type-like conformation, thereby reactivating the transcriptional activity of mutant $\mathrm{p} 53$. Here we report the identification of the novel p53 rescue compound P53R3, a quinazoline that is structurally unrelated to the styrylquinazoline CP-31398 or the quinuclidinone analogue PRIMA-1 (Figure 1).

Glioblastoma is an invariably lethal type of cancer paradigmatic for resistance to radiotherapy and chemotherapy. We have previously explored the possible therapeutic potency of p53-based cell death induction in glioma cells using a p53-based designer sequence referred to as chimeric tumour suppressor (CTS) $-1^{3}$ or the p53 rescue compound, CP-31398. ${ }^{4}$ Here we used a panel of human glioma cell lines to assess the growth inhibitory and cytotoxic properties of the novel p53 rescue compound.

The death ligand Apo2 ligand/TNF-related apoptosisinducing ligand (Apo2L/TRAIL) has become a candidate proapoptotic agent for the experimental treatment of glioblastoma. ${ }^{5,6}$ Apo2L/TRAIL interacts with several cell surface receptors: death receptors (DR) 4 and 5 promote apoptosis whereas decoy receptors (DcR) 1 and 2 do not. p53 rescue drugs are predicted to enhance the cytotoxicity of Apo2L/TRAIL since p53 induces the expression of the proapoptotic Apo2L/TRAIL receptors DR 4 and $5 .^{7,8}$ Accordingly, we also explored a possible sensitisation to Apo2L/TRAIL-induced apoptosis of glioma cells by this novel p53 rescue agent.

${ }^{1}$ Laboratory of Molecular Neuro-Oncology, Department of General Neurology, Hertie Institute for Clinical Brain Research, University of Tübingen School of Medicine, Tübingen D-72076, Germany; ${ }^{2}$ Department for Obstetrics and Gynecology, Interdisciplinary Center for Clinical Research (IZKF), University of Würzburg, JosefSchneider-Strasse 4, Würzburg D-97080, Germany; ${ }^{3}$ Schering-Plough Research Institute, 2015 Gallopping Hill Road, Kenilworth, NJ 07033, USA

${ }^{4}$ Current address: RNA Biology Group, Max-Planck Institute for Biochemistry, Martinsried D-82152, Germany

*Corresponding author: J Wischhusen, Department for Obstetrics and Gynecology, Interdisciplinary Center for Clinical Research (IZKF), University of Würzburg, JosefSchneider-Strasse 4, Würzburg D-97080, Germany. Tel: + 49931 20125291; Fax: + 49931 20125406; E-mail: Wischhusen_J@klinik.uni-wuerzburg.de

Keywords: glioma; drug design; p53; Apo2L/TRAIL; apoptosis

Abbreviations: Apo2L, Apo2 ligand; BAl1, brain-specific angiogenesis inhibitor 1; CD95L, CD95 ligand; ChIP, chromatin immunoprecipitation; Chk1, checkpoint kinase 1; DcR1/2, decoy receptor 1/2; DEVD-amc, Asp-Glu-Val-Asp-7-amino-4-methylcoumarin; DR4/5, death receptor 4/5; GADD45, growth arrest and DNA damage 45; GML, glycosylphosphatidylinositol-anchored molecule-like protein gene; Mdm2, mouse double minute 2; miR-34a, microRNA-34a; P2XM, P2X specifically expressed in skeletal muscle; PBL, peripheral blood lymphocytes; PERP, p53 effector related to PMP-22; PI, propidium iodide; PIG-3, p53-inducible gene 3; PIG-6, p53-inducible gene 6; PRIMA-1, p53 reactivation and induction of massive apoptosis; PUMA, p53-upregulated modulator of apoptosis; SFI, specific fluorescence index; TGF- $\alpha$, transforming growth factor $\alpha$; TNF- $\alpha$, tumour necrosis factor $\alpha$; TNF-R1, TNF receptor 1; TP53TG1, p53 target gene 1; TRAIL, TNF-related apoptosis-inducing ligand; TSP-1, thrombospondin-1; WIG-1, wild-type p53-induced gene 1; WIP1, wild-type p53-induced phosphatase 1; zVAD-fmk, benzyloxycarbonyl-Val-Ala-Asp-(OMe) fluoromethyl ketone

Received 01.6.07; revised 06.11.07; accepted 26.11.07; Edited by P Mehlen; published online 18.1.08 
a<smiles>COC(=O)C(Nc1nc(CN2CCN(C(c3ccc(Cl)cc3)c3ccc(Cl)cc3)CC2)nc2ccccc12)C(C)C</smiles>

b

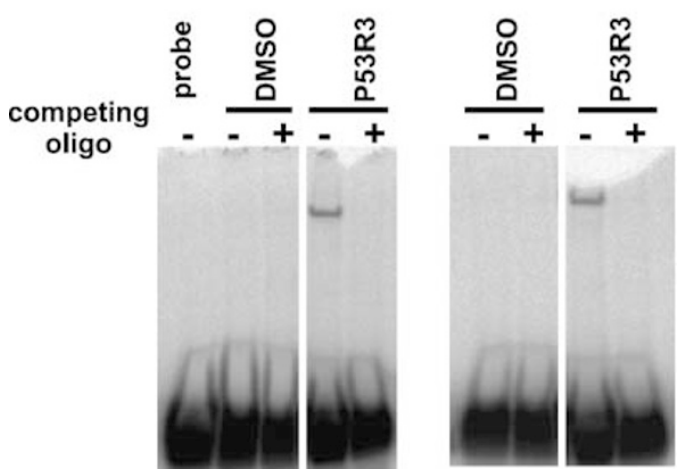

Figure 1 P53R3 restores DNA binding of mutant p53. (a) Structure of P53R3. (b) WiDr $\left(\mathrm{p} 53^{\mathrm{R} 273 \mathrm{H}}\right)$ and $\mathrm{KLE}\left(\mathrm{p} 53^{\mathrm{R} 175 \mathrm{H}}\right)$ cells were treated or not treated with P53R3 $(10 \mu \mathrm{g} / \mathrm{ml})$ for $24 \mathrm{~h}$, before nuclear extracts were prepared and incubated with ${ }^{33} \mathrm{P}$-labelled p53 consensus oligonucleotide in the absence or presence of the unlabelled p53 consensus oligonucleotide. The complexes were analysed by electrophoresis on a $6 \%$ TBE gel

\section{Results}

Identification of a novel class of p53 agonists by highthroughput screening. The p53 reactivator (P53R3) was identified from a small library of compounds using an in vitro DNA binding assay (Figure 1a). Briefly, the recombinant p53 DNA binding domain (amino acids 92-312) fused to glutathione synthase transferase (GST) was pre-incubated with the compounds to be screened prior to incubation with the biotinylated double-stranded deoxy-oligonucleotide corresponding to the p53 binding sequence. The p53bound oligonucleotide was captured by streptavidin-coated magnetic beads and measured by an antibody to GST via a chemoluminescence assay. ${ }^{9}$ To validate the results obtained by a high-throughput DNA binding assay, WiDr cells, colon tumour cells harbouring $\mathrm{p} 53^{\mathrm{R} 273 \mathrm{H}}$ and KLE cells with $\mathrm{p} 53^{\mathrm{R} 175 \mathrm{H}}$ were treated with the compounds and nuclear extracts were prepared. DNA binding assays were performed with the extracts. ${ }^{9}$ As shown in Figure 1b, nuclear extracts from P53R3-treated cells exhibit DNA binding activity of p53, whereas nuclear extracts from dimethylsulphoxide (DMSO)-only-treated cells did not form a complex with the ${ }^{33} \mathrm{P}$-labelled p53-binding oligonucleotide. Thus, this molecule restores p53-specific DNA binding activity to p53 ${ }^{\mathrm{R} 273 \mathrm{H}}$, a DNA contact mutant and $\mathrm{p} 53^{\mathrm{R} 175 \mathrm{H}}$, a structural mutant, two of the most frequent oncogenic alterations in $p 53 .{ }^{10}$

p53-dependent and -independent antiproliferative and cytotoxic effects of P53R3 and PRIMA-1 on human malignant glioma cell lines. To obtain a cell-based experimental system that allows to distinguish between p53-dependent and -independent effects of the novel compound, we stably transfected p53 null LN-308 human glioma cells with a control plasmid or plasmids encoding the P53R3-responsive mutants $\mathrm{p} 53^{\mathrm{R} 175 \mathrm{H}}, \mathrm{p} 53^{\mathrm{R} 248 \mathrm{~W}}$ and p53 ${ }^{\mathrm{R} 273 \mathrm{H}}$ (Figure 2a). Since $\mathrm{LN}-308$ cells express no endogenous p53 or p73, ${ }^{11}$ this allows for the investigation of P53R3-mediated effects in a 'clean' experimental system. Because p53 plays an important role in cell cycle control and in the induction of apoptosis in response to various cellular stress signals, we asked whether the p53 rescue compound P53R3 exerts p53-dependent antiproliferative or cytotoxic effects in this experimental system. PRIMA $-1^{2}$ was included as a reference compound. [Methyl ${ }^{3} \mathrm{H}$ ] thymidine incorporation was measured to determine the rate of cell proliferation. As shown in Figure 2b, P53R3 inhibited the proliferation of the LN-308 sublines expressing mutant p53 plasmids in a p53-dependent manner. $\mathrm{p} 53^{\mathrm{R} 175 \mathrm{H}}$-dependent effects were strong and significant over a broad range of concentrations. $\mathrm{p} 53^{\mathrm{R} 273 \mathrm{H}}$-dependent effects were weaker and required high concentrations of P53R3. p53 ${ }^{\mathrm{R} 248 \mathrm{~W}}$ reactivation by $\mathrm{P} 53 \mathrm{R} 3$ induced a more pronounced proliferation inhibition than observed with $\mathrm{p} 53^{\mathrm{R} 273 \mathrm{H}}$. Curiously, thymidine incorporation in LN-308 neo cells was stimulated by higher concentrations of P53R3. Irrespective of p53 status, high concentrations of PRIMA-1 also induced cell death, as revealed by light microscopy (data not shown) whereas PRIMA-mediated p53-dependent antiproliferative effects were weak in this system.

To investigate the mechanism of growth inhibition in more detail, we analysed the effects of P53R3 and PRIMA-1 on cell cycle distribution by flow cytometry. In LN-308 p53 ${ }^{\mathrm{R} 175 \mathrm{H}}$ and $\mathrm{LN}-308 \mathrm{p5} 3^{\mathrm{R} 273 \mathrm{H}}, \mathrm{P} 53 \mathrm{R} 3$ induced a strong decrease in $\mathrm{S}$ phase cells and $a G_{0} / G_{1}$ cell cycle arrest (Figure $2 c$ ), which was not observed with $\mathrm{LN}-308$ control transfectants. Surprisingly, cell cycle distribution of LN-308 p53 ${ }^{\mathrm{R} 248 \mathrm{~W}}$ cells was hardly altered by P53R3. Considering that P53R3 strongly inhibited $\left[\right.$ methyl- ${ }^{3} \mathrm{H}$ ] thymidine uptake by this subline (Figure 2b), it appears that P53R3 may not only induce cell cycle arrest at specific stages, but also generally slow down cell cycle progression, depending on the p53 mutant. Remarkably, P53R3 did not exhibit cytotoxic effects even at concentrations close to its solubility limit $(33 \mu \mathrm{g} / \mathrm{ml})$. PRIMA-1, in contrast, left the $S$ phase unaffected at low concentrations and had only minor effects on cell cycle distribution of LN-308 neo, p53 $3^{\mathrm{R} 248 \mathrm{~W}}$ and $\mathrm{p5} 3^{\mathrm{R} 175 \mathrm{H}}$ cells (Figure 2c). However, it decreased the number of $p 53^{\mathrm{R} 273 \mathrm{H}}$ cells in the $G_{0} / G_{1}$ and $S$ phase and increased the number of $G_{2} / M$ phase cells. At higher concentrations, PRIMA-1 induced strong DNA degradation in $p 53^{\mathrm{R} 273 \mathrm{H}}$ cells but had no major growth inhibitory effects on $\mathrm{LN}-308$ neo, $\mathrm{p} 53^{\mathrm{R} 175 \mathrm{H}}$ and $\mathrm{p} 53^{\mathrm{R} 248 \mathrm{~W}}$ cells. Taken together, these data indicate that P53R3 displays p53-dependent antiproliferative effects and does not exert p53-independent cytotoxic effects on tumour cells.

Importantly, P53R3 showed no apparent cytotoxic effects on non-neoplastic control cells like human fibroblasts, human peripheral blood lymphocytes (PBL) or rat cerebellar granule neurons (Table 1). In contrast, PRIMA-1 was cytotoxic to human fibroblasts at concentrations required to induce p53dependent cytotoxicity in LN-308 $\mathrm{p}^{2} 3^{\mathrm{R} 273 \mathrm{H}}$ cells (Table 1 and 
p53

$\beta$-Actin

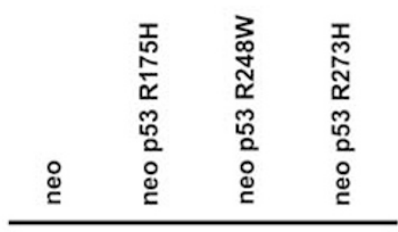

LN-308 b

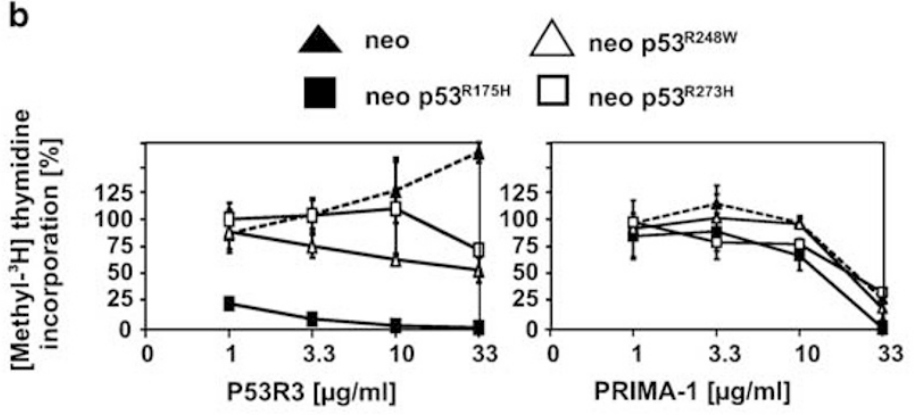

C
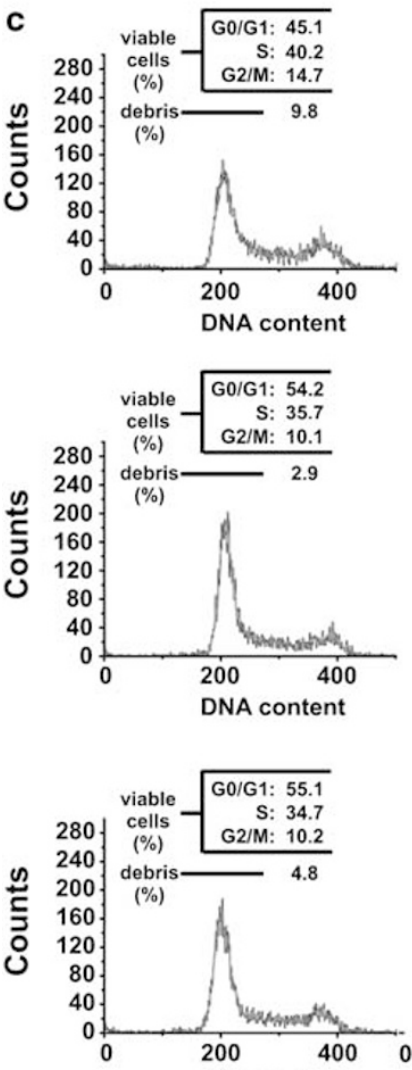

DNA content

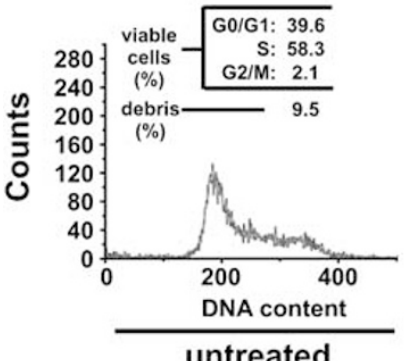

untreated
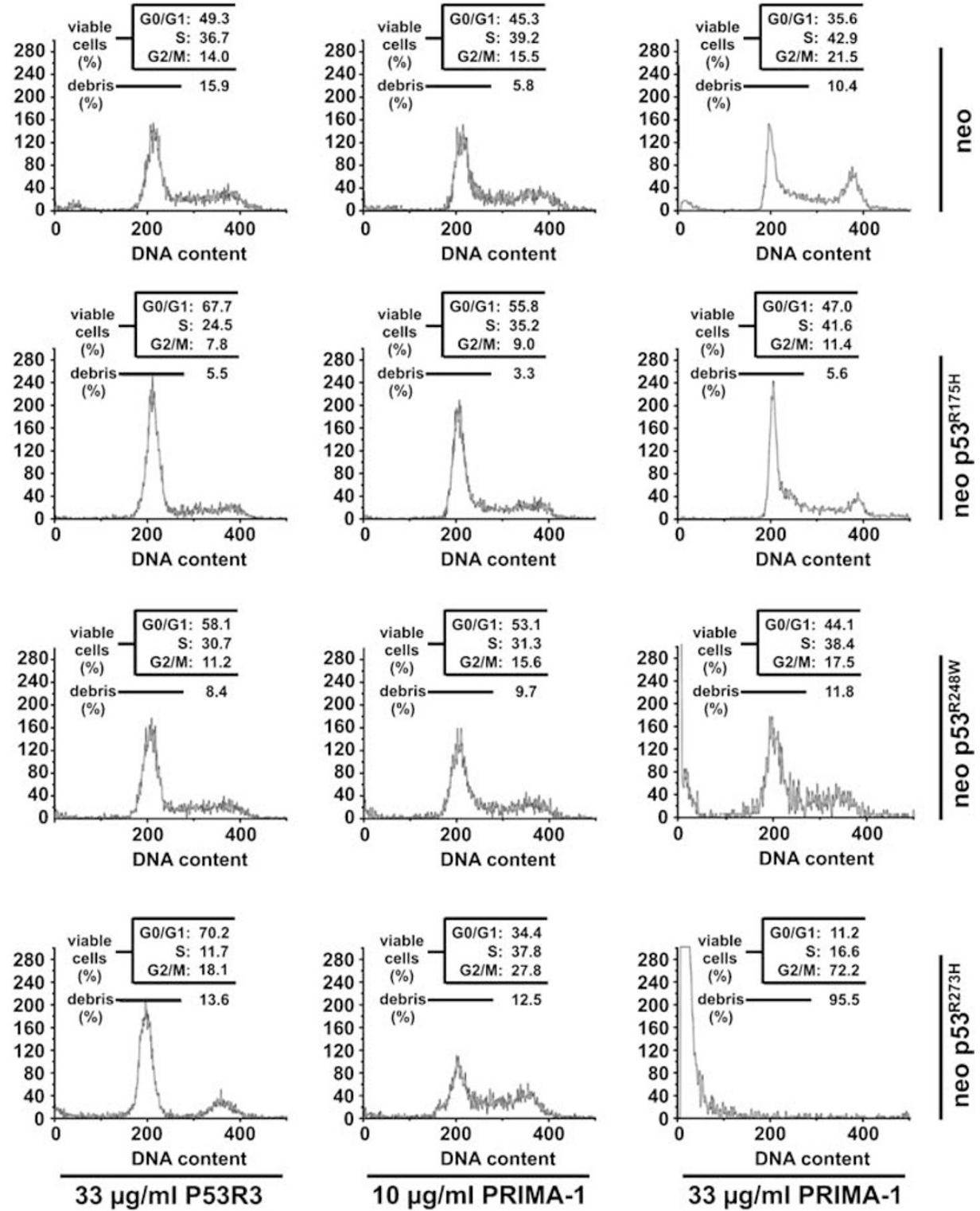

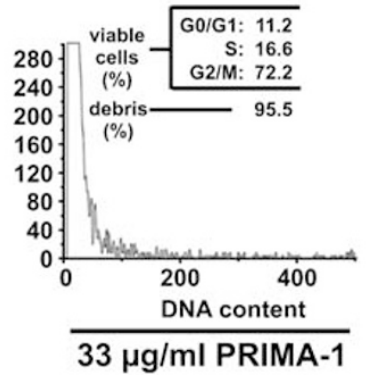

Figure 2 p53-dependent and -independent effects of P53R3 and PRIMA-1 in mutant p53-transfected LN-308 cells. (a) p53 levels in the transfected LN-308 sublines were assessed by immunoblot. Equal loading was ascertained by $\beta$-actin staining. (b) LN-308 neo (filled triangles, dashed lines), p53 ${ }^{\mathrm{R} 175 \mathrm{H}}$ (filled squares), p53 ${ }^{\mathrm{R} 248 \mathrm{~W}}$ (open triangles) or $\mathrm{p} 53^{\mathrm{R} 273 \mathrm{H}}$ (open squares) cells $\left(10^{4}\right.$ cells per well) were seeded to 96 well plates, adhered overnight and treated for $24 \mathrm{~h}$. At $16 \mathrm{~h}$, the cells were pulsed with $0.25 \mu \mathrm{Ci}$ per well [methyl- ${ }^{3} \mathrm{H}$ ] thymidine for $8 \mathrm{~h}$. [Methyl- ${ }^{3} \mathrm{H}$ ] thymidine incorporation was determined by liquid scintillation counting. Data were normalised to a DMSO solvent control. (c) LN-308 p53 and control transfectants were incubated with P53R3 (33 $\mu \mathrm{g} / \mathrm{ml})$ or PRIMA-1 (10 or $33 \mu \mathrm{g} / \mathrm{ml})$ for $18 \mathrm{~h}$, fixed, permeabilised, stained with PI and analysed by flow cytometry. The figure shows representative examples of flow cytometry profiles and the distribution of the cells to the indicated histogram regions (\%) 
Table 1 Growth inhibitory effects of p53 rescue compounds on non-neoplastic cells

\begin{tabular}{lcc}
\hline & \multicolumn{2}{c}{$\mathrm{EC}_{\mathbf{5 0}}(\mathbf{2 4} \mathrm{h})(\boldsymbol{\mu g} / \mathbf{m l})$} \\
\cline { 2 - 3 } Cell type & P53R3 & PRIMA-1 \\
\hline Human fibroblasts & $>33$ & 30 \\
Human PBL & $>33$ & $>33$ \\
Rat cerebellar granule neurons & $>33$ & $>33$ \\
\hline
\end{tabular}

The cells were incubated with increasing concentrations of p53 rescue compounds for $24 \mathrm{~h}$. Growth inhibition was assessed using crystal violet staining (fibroblasts), flow cytometry (PBL) or Alamar Blue staining (Biosource International, Camarillo, CA, USA) (neurons). To identify viable cells from cell cycle data, we defined all cells with a DNA content of less than $2 n$ as dead. $E_{50}$ values were calculated by graphical interpolation

Figure 2c) and failed to trigger $p 53^{\mathrm{R} 175 \mathrm{H}_{-}}$and $\mathrm{p} 53^{\mathrm{R} 248 \mathrm{~W}}$. dependent growth inhibition (Figure $2 b$ and $c$ ). These results show that P53R3 is more specific to neoplastic cells than PRIMA-1 and affects a broader spectrum of p53 mutants than PRIMA-1.

P53R3 enhances the recruitment of wild-type and mutant p53 to target promoters. Having found that P53R3 inhibits the proliferation of mutant p53-transfected LN-308 glioma cells while p53-deficient LN-308 control cells are not affected, we investigated whether P53R3 can also interact with endogenous mutant or wild-type p53 in glioma cells. We treated p53 wild-type (LNT-229) and p53 ${ }^{\mathrm{M} 2371}$ (T98G) glioma cells with P53R3 and performed chromatin immunoprecipitation (ChIP) with a p53-specific antibody (Figure 3). P53R3 enhanced the binding of $\mathrm{p} 53^{\mathrm{M} 237 \mathrm{I}}$ to all of the six target promoters and the binding of wild-type p53 to five of the six target sequences. This demonstrates that P53R3 can be used to restore p53 target binding in tumour cells.

P53R3 induces p53-dependent expression of numerous p53 target genes. We further used RNA interference to deplete p53 from these two cell lines (Figure 4a). The resulting p53 knockdown (pSUPERpuro p53) and control (pSUPERpuro) cells were then used to broadly analyse the transcriptional effects of P53R3 on p53 wild-type LNT-229 or mutant T98G glioma cells by real-time PCR (RT-PCR). Considering an mRNA upregulation $\geqslant 1.5$ to be relevant, 15 of 25 p53-responsive targets were induced in T98G $\left(p 53^{\mathrm{M} 2371}\right)$ cells, whereas only 10 targets were induced in LNT-229 (p53 wt) cells (Figure 4b). This shows that P53R3 exerts stronger effects on cells bearing mutant p53 than on wild-type p53 cells. In p53 knockdown cells, the induction of target mRNAs was either strongly decreased or altogether absent, which confirms that the observed effects specifically depend on p53. A small number of p53 targets was also repressed by $P 53 R 3$. This effect occurred mainly in the $p 53$ wild-type cell line, suggesting that P53R3 preferentially targets p53 towards a certain set of responsive promoters, possibly at the expense of others. Taken together, these results indicate that $\mathrm{P} 53 \mathrm{R} 3$ triggers the transcription of numerous p53 target genes in glioma cells, predominantly through the activation of non-functional p53. On the protein
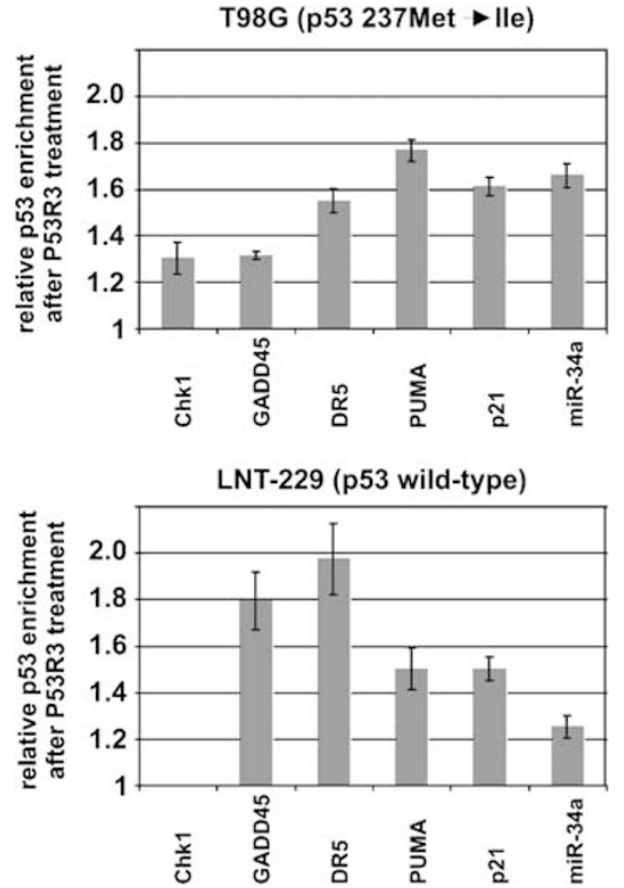

Figure 3 P53R3 induces p53 recruitment to target promoters in glioma cells. T98G cells (upper panel) or LNT-229 cells (lower panel) were treated or not treated with P53R3 $(10 \mu \mathrm{g} / \mathrm{ml})$ for $20 \mathrm{~h}$. Binding of p53 to the indicated target promoters was determined by chromatin immunoprecipitation and subsequent real-time PCR analysis. Target gene-specific $C_{\text {t }}$ values were normalised to input and GAPDH controls. The figure shows the relative enrichment in target promoter binding of $\mathrm{p53}$, calculated from the ratio of P53R3-treated versus DMSO control samples

level, we confirmed the p53-dependent induction of p21/ CIP1/WAF1 in LNT-229, corroborating the mRNA data (Figure $4 \mathrm{~b}$ and $\mathrm{c}$ ).

P53R3 induces DR5 surface expression on human malignant glioma cell lines. The P53R3-dependent induction of proapoptotic targets such as p53-upregulated modulator of apoptosis (PUMA) or death receptor 5 (DR5) on mRNA level raises the possibility that P53R3 could also be utilised to trigger tumour cell death in the presence of additional proapoptotic stimuli. In this context, we next set out to investigate whether P53R3 modulates the expression of Apo2L/TRAIL receptors on the surface of glioma cells. We therefore exposed 12 human glioma cell lines to P53R3 and monitored the surface expression of the Apo2L/TRAIL receptors DR4, DR5, DcR1 and DcR2 by flow cytometry (Table 2). Even though the related proapoptotic Apo2L/ TRAIL receptor DR4 had previously been reported to be p53inducible, ${ }^{7}$ only DR5 was induced in all cell lines. The surface expression of the other Apo2L/TRAIL receptors remained unaltered in most cell lines except for D247MG and LN-319, which showed a moderate induction of DcR2. Figure $5 \mathrm{a}$ shows representative flow cytometry profiles for DR5 expression in LNT-229 and T98G cells. Corresponding profiles for the related death receptors, CD95 and TNF receptor (TNF-R) 1 (p55) are shown in Figure 5b for T98G cells. Interestingly, the cell surface levels of these TNF-R family members were not induced by P53R3. 


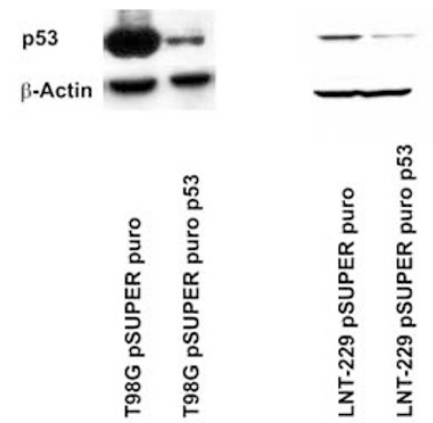

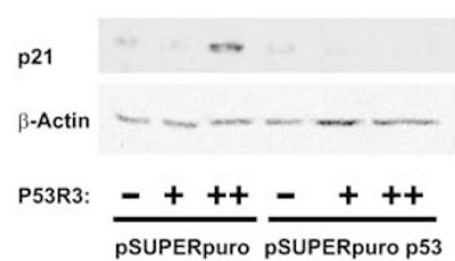

b

T98G (p53 237Met $\rightarrow$ Ile)

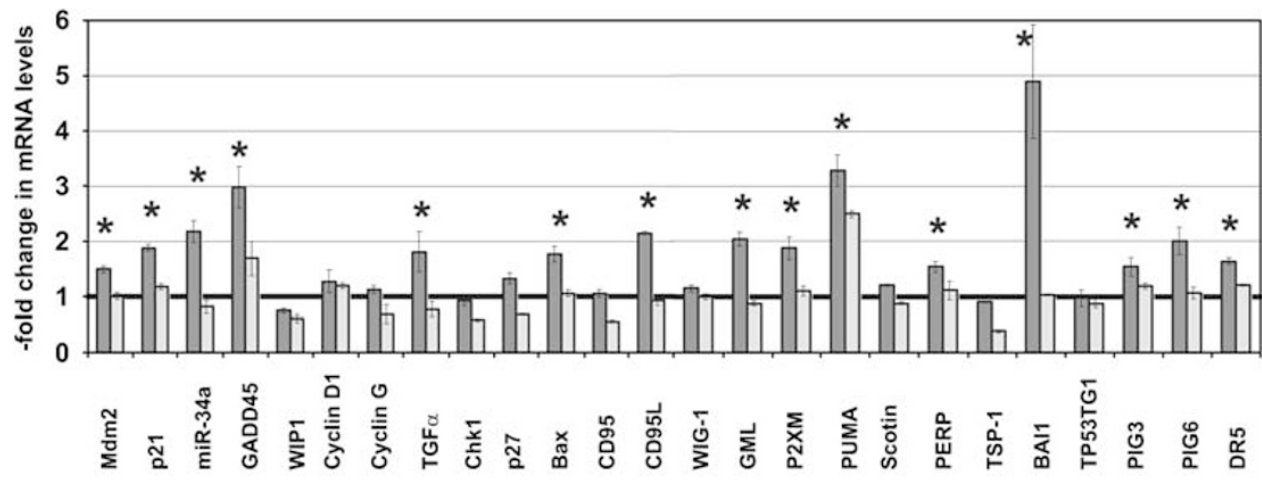

LNT-229 (p53 wild-type)

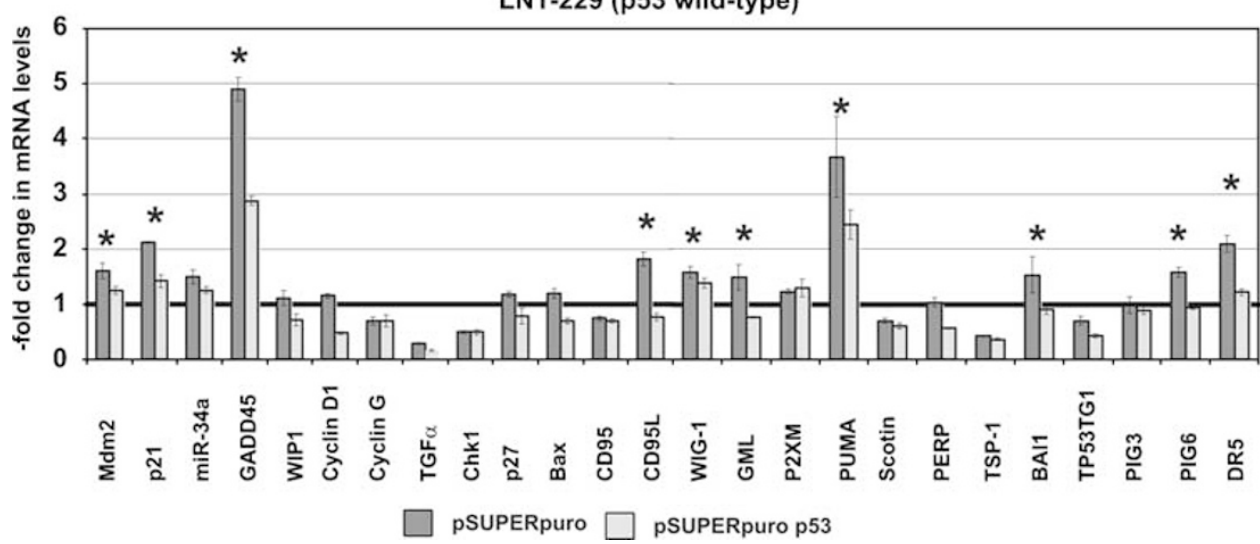

Figure 4 P53R3 induces p53-dependent expression of p53 target genes. (a) p53 expression of the sublines was determined by immunoblot (upper panel), using $\beta$-actin as a loading control (lower panel). (b) T98G and LNT-229 pSUPERpuro p53 or control transfectants were treated with P53R3 (10 $\mu \mathrm{g} / \mathrm{ml}$ ) or DMSO control for $20 \mathrm{~h}$. mRNA levels were determined by real-time PCR. The figure shows mRNA levels after P53R3 treatment, normalised to mRNA levels of the DMSO control. mRNAs that were significantly $(P<0.05)$ induced by $\geqslant 1.5$-fold in control cells are indicated by asterisks. (c) LNT-229 pSUPERpuro p53 or control cells were treated with DMSO $(-), 10 \mu \mathrm{g} / \mathrm{ml}$ P53R3 $(+)$ or $33 \mu \mathrm{g} / \mathrm{ml} \mathrm{P53R3}(++)$ for $16 \mathrm{~h} . \mathrm{p} 21$ expression was detected by immunoblot

While DR5 mRNA induction was sensitive to the knockdown of p53 (Figure 4b), analysis of DR5 surface expression in 12 glioma cell lines yielded a more complex picture: DR5 was induced in glioma cell lines bearing wild-type (U87MG, D247, LNT-229, A172), mutant (LN-18, U138MG, LN-428, T98G, LN-319, U251MG, U373MG) or no (LN-308) p53 (Tables 2 and 3 ). This raised the question on the extent to which the P53R3-induced upregulation of DR5 depends on p53. Therefore, we performed flow cytometry on permeabilised or non-permeabilised LNT-229 and T98G pSUPERpurop53 and pSUPERpuro control cells (Figure 5c). These experiments revealed that treatment with P53R3 increased total DR5 protein levels only when p53 was present. DR5 surface expression, however, could also be upregulated in the absence of p53 (Figure 5c). Taken together, these data suggest that P53R3 can recruit mutant or wild-type p53 to the DR5 promoter (Figure 3), which results in a p53-dependent increase in DR5 mRNA (Figure 4b) and total DR5 protein (Figure 5c). Nevertheless, P53R3 may also induce the translocation of DR5 protein to the cell surface in a p53independent manner. This may explain the P53R3-mediated induction of DR5 surface expression in the p53 null cell line LN-308, which was not reflected by an increase in DR5 mRNA or total protein (data not shown). 
Table 2 Modulation of Apo2L/TRAIL receptor expression in human malignant glioma cell lines by P53R3

\begin{tabular}{|c|c|c|c|c|c|c|c|c|c|c|c|c|}
\hline \multirow[b]{2}{*}{ Cell line } & \multicolumn{3}{|c|}{ DR4 } & \multicolumn{3}{|c|}{ DR5 } & \multicolumn{3}{|c|}{ DcR1 } & \multicolumn{3}{|c|}{ DcR2 } \\
\hline & $\begin{array}{c}\text { SFI- } \\
\text { untreated }\end{array}$ & $\begin{array}{c}\text { SFI- } \\
\text { treated }\end{array}$ & $\begin{array}{l}\text { Relative } \\
\text { change }\end{array}$ & $\begin{array}{c}\text { SFI- } \\
\text { untreated }\end{array}$ & $\begin{array}{c}\text { SFI- } \\
\text { treated }\end{array}$ & $\begin{array}{c}\text { Relative } \\
\text { change }\end{array}$ & $\begin{array}{c}\text { SFI- } \\
\text { untreated }\end{array}$ & $\begin{array}{c}\text { SFI- } \\
\text { treated }\end{array}$ & $\begin{array}{l}\text { Relative } \\
\text { change }\end{array}$ & $\begin{array}{c}\text { SFI- } \\
\text { untreated }\end{array}$ & $\begin{array}{c}\text { SFI- } \\
\text { treated }\end{array}$ & $\begin{array}{c}\text { Relative } \\
\text { change }\end{array}$ \\
\hline LN-18 & 5.0 & 4.5 & 0.9 & 6.3 & 12.9 & 2.0 & 1.0 & 1.1 & 1.0 & 2.0 & 2.6 & 1.3 \\
\hline U138MG & 8.7 & 8.7 & 1.0 & 62.6 & 80.7 & 1.3 & 1.1 & 1.1 & 1.0 & 2.6 & 2.6 & 1.0 \\
\hline U87MG & 3.2 & 3.3 & 1.0 & 50.3 & 74.9 & 1.5 & 1.3 & 1.3 & 1.0 & 21.3 & 26.4 & 1.2 \\
\hline LN-428 & 6.3 & 7.0 & 1.1 & 69.8 & 99.9 & 1.4 & 1.2 & 1.4 & 1.2 & 1.3 & 1.2 & 0.9 \\
\hline D247MG & 4.8 & 4.5 & 0.9 & 35.2 & 62.7 & 1.8 & 1.3 & 1.3 & 1.0 & 4.1 & 7.2 & 1.8 \\
\hline T98G & 8.3 & 8.4 & 1.0 & 107.3 & 138.3 & 1.3 & 1.0 & 1.0 & 1.0 & 1.6 & 1.7 & 1.0 \\
\hline LN-319 & 10.7 & 12.4 & 1.2 & 31.6 & 45.3 & 1.4 & 1.3 & 1.6 & 1.2 & 3.3 & 5.6 & 1.7 \\
\hline LNT-229 & 1.9 & 1.7 & 0.9 & 5.4 & 20.4 & 3.8 & 1.0 & 1.0 & 1.0 & 1.1 & 1.0 & 1.0 \\
\hline A172 & 5.1 & 5.4 & 1.1 & 96.5 & 115.6 & 1.2 & 1.2 & 1.2 & 1.1 & 3.1 & 3.3 & 1.1 \\
\hline U251MG & 5.4 & 4.7 & 0.9 & 28.4 & 35.2 & 1.2 & 1.0 & 1.0 & 1.0 & 2.4 & 2.9 & 1.2 \\
\hline U373MG & 4.9 & 4.7 & 1.0 & 32.8 & 43.7 & 1.3 & 1.0 & 1.0 & 1.0 & 2.3 & 1.8 & 0.8 \\
\hline LN-308 & 2.8 & 2.8 & 1.0 & 17.8 & 28.4 & 1.6 & 1.1 & 1.1 & 1.0 & 2.7 & 2.4 & 0.9 \\
\hline
\end{tabular}

The cells were treated for $16 \mathrm{~h}$ with P53R3 $(10 \mu \mathrm{g} / \mathrm{ml})$. Apo2L/TRAIL receptor expression was analysed by flow cytometry and SFI (specific fluorescence index) values were calculated

P53R3 sensitises glioma cell lines to Apo2L.0-induced cell death. Next we investigated whether P53R3 sensitised human glioma cells to Apo2L.0-induced cell death. The cells were pretreated with largely subtoxic concentrations of P53R3 and then stimulated with Apo2L.0. Light microscopy confirmed that the observed losses in cell density were due to decreased survival since the cells rounded off and detached (data not shown). These survival data were analysed by the fractional product method. ${ }^{13}$ Nine of the 12 glioma cell lines (LN-18, U87MG, LN-428, D247, T98G, LNT229, A172, U251MG, U373MG) were strongly sensitised by P53R3 to Apo2L.0-induced cell death (Figure 6a). No synergy was observed in the p53 null cell line LN-308. Similarly, suppression of endogenous p53 by RNA interference desensitised wild-type p53 LNT-229 or mutant p53 T98G cells for the effects of co-treatment with P53R3 and Apo2L.0 (Figure 6b). A contribution of p53-dependent effects to the synergy of P53R3 and Apo2L.0 was further ascertained in HCT116 p53 ${ }^{\text {wt }}$ cells, which displayed an albeit weak synergy between P53R3 and Apo2L.0 whereas no synergistic effects were observed in HCT116 $\mathrm{p}^{-1} 3^{-/}$cells (data not shown).

To explore possible effects of the combined treatment on non-neoplastic human cells, we tested human PBL for synergy between P53R3 and Apo2L.0. As shown in Figure 6c, the cytotoxicity of P53R3 was not augmented by a cotreatment with Apo2L.0, demonstrating that non-neoplastic cells can resist this treatment. We further addressed the question whether the synergy was paralleled by a sensitisation to related apoptotic pathways triggered by CD95 ligand (CD95L) or TNF- $\alpha$. Interestingly, P53R3 effectively promoted Apo2L.0-induced cell death in T98G and A172 cells, but failed to sensitise these cell lines to CD95L- and TNF- $\alpha$-induced apoptosis (Figure $6 \mathrm{~d}-\mathrm{i}$ ), suggesting that the mechanism of sensitisation was specific to Apo2L/TRAIL-induced cell death. In contrast, CD95L and TNF- $\alpha$ killed T98G cells in the presence of cycloheximide, ${ }^{15}$ indicating that the lack of synergy was not due to a general resistance of the cells to these death ligands.

To investigate whether synergistic caspase activation by P53R3 and Apo2L.0 was involved in cell death induced by P53R3 and Apo2L, we measured the cleavage of the synthetic caspase substrate Asp-Glu-Val-Asp-7-amino-4methylcoumarin (DEVD-amc) (Figure 7a). At lower concentrations $(+)$, neither P53R3 nor Apo2L.0 alone induced DEVD-amc cleavage in T98G cells, whereas co-treatment yielded a strong signal comparable to that achieved by co-treatment with $\mathrm{CD} 95 \mathrm{~L}$ and cycloheximide. At higher concentrations $(++, 1 \mu \mathrm{g} / \mathrm{ml})$, Apo2L.0 alone still failed to induce caspase activation. Crystal violet staining confirmed that this lack of detectable caspase activity was not due to cells already having undergone Apo2L.0-induced cell death (data not shown). Cytotoxic concentrations of P53R3 $(++$, $33 \mu \mathrm{g} / \mathrm{ml}$ ) also induced DEVD-amc cleavage when applied alone, but this caspase activity was not essential for P53R3mediated cytotoxicity since addition of the broad-spectrum caspase inhibitor benzyloxycarbonyl-Val-Ala-Asp-(OMe) fluoromethyl ketone (zVAD-fmk) did not protect the cells from the cytotoxic effects of P53R3 (data not shown). In line with these results, a synergistic cleavage of caspases 8 and 3 and of a caspase substrate, poly-ADP-ribose polymerase (PARP), was detected in T98G cells upon co-treatment (Figure 7b). The crucial importance of caspases in the synergistic cell death induced by P53R3 and Apo2L.0 was further confirmed by addition of zVAD-fmk, which blocked synergy and all cytotoxic effects of Apo2L.0 (Figure 7c). Thus, P53R3 facilitated the cell death cascade triggered by Apo2L.0, but not vice versa.

\section{Discussion}

The refunctionalisation of mutant p53 in tumours is a promising approach to cancer therapy, especially since recent studies have shown that p53 does not only prevent cancer during early stages of tumorigenesis, ${ }^{16}$ but also acts as an effective tumour suppressor during late stages of lymphoma, liver carcinoma and sarcoma. ${ }^{17-19}$ While this has been demonstrated in genetically defined mouse models harbouring either a doxycyclin-inducible knockin of $p 53^{19}$ or a doxycyclin-dependent vector for p53-specific RNA interference ${ }^{17}$ or a Cre-recombinase-susceptible ('Floxed') stop codon preceding $\mathrm{p} 53,{ }^{18}$ the human disease is not 
a
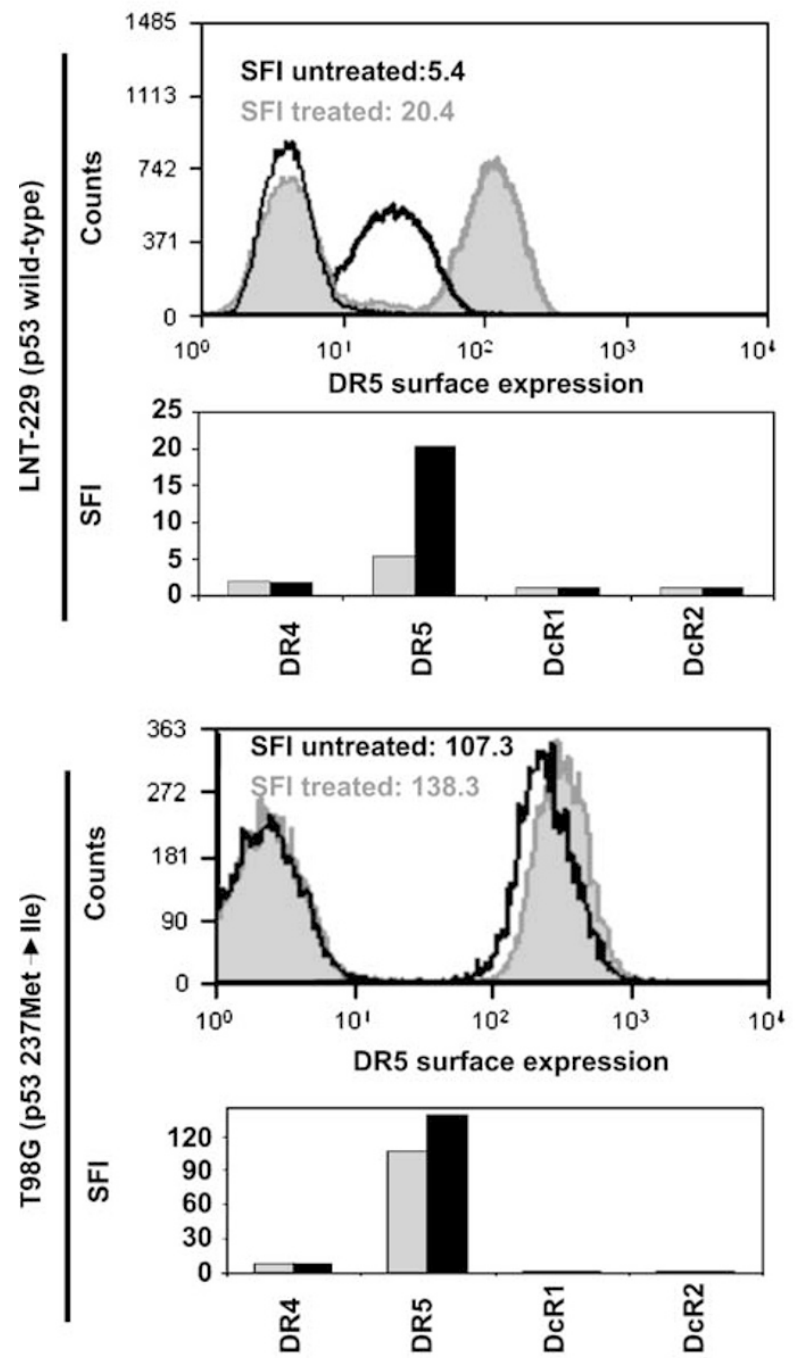

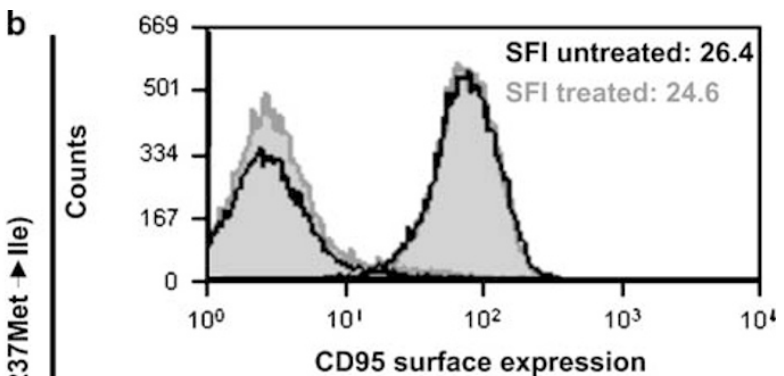

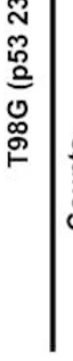

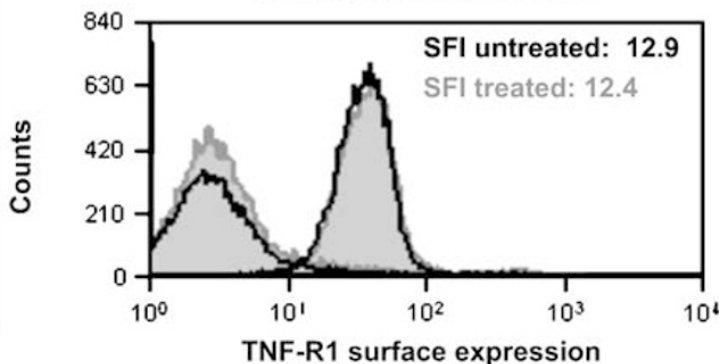

C
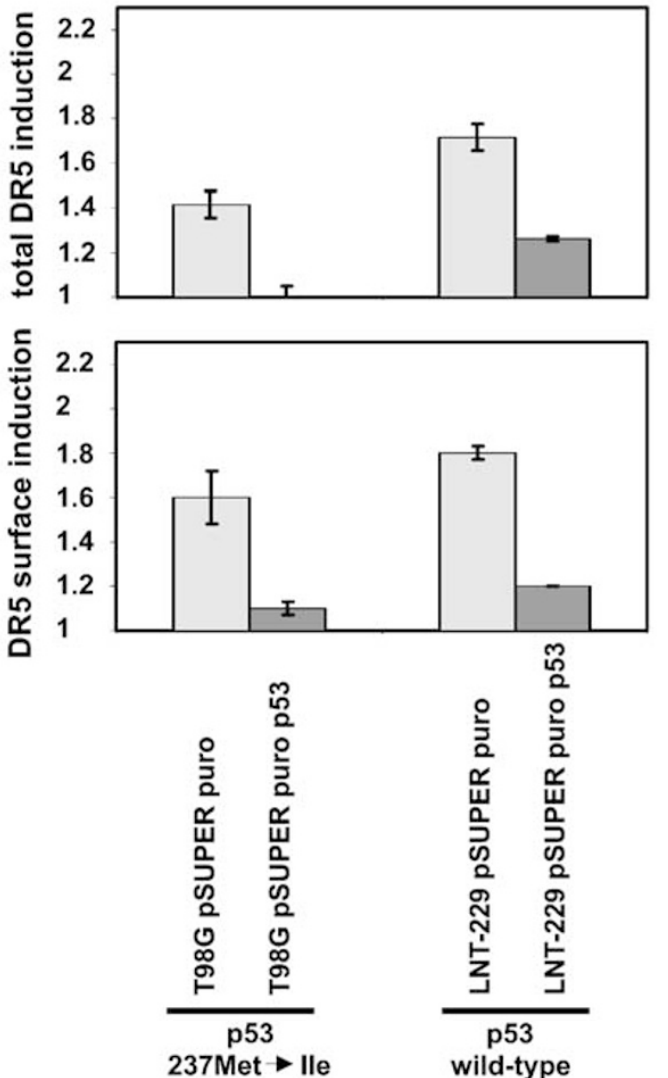

Figure 5 P53R3 induces a p53-dependent upregulation of DR5 in human glioma cell lines. (a) LNT-229 or T98G cells were treated with P53R3 (10 $\mu \mathrm{g} / \mathrm{ml})$ for $16 \mathrm{~h}$. Cell surface expression of DR4, DR5, DcR1 and DcR2 was analysed by flow cytometry. The upper panels show the modulation of DR5 expression by P53R3 (filled histograms) compared to the untreated control sample (open histograms). The histograms of the isotype control samples are located on the left, the DR5 samples are displayed on the right. Please note the logarithmic scale. Specific fluorescence indexes (SFI) for all Apo2L/TRAIL-binding cell surface receptors are displayed in the lower panels. (b) T98G cells were treated with P53R3 or left untreated and analysed for the expression of CD95 (upper panel) or TNF-R1 (lower panel). Data are displayed as filled (treated samples) or open histograms (untreated controls). Isotype controls are displayed on the left, stained samples are shown on the right. (c) T98G and LNT-229 pSUPERpuro p53 or control transfectants were treated with P53R3 $(10 \mu \mathrm{g} / \mathrm{ml})$ for $16 \mathrm{~h}$. For all graphs, DR5 expression of the P53R3-treated cells was normalised to the corresponding DMSO-treated cells to calculate the induction of DR5. Upper panel: the cells were fixed, permeabilised and analysed for total DR5 protein expression by flow cytometry. Lower panel: the cells were analysed for DR5 surface expression by flow cytometry 
Table 3 Genetic p53 status, p53 reporter activity and relative p53 protein level of human glioma cell lines

\begin{tabular}{|c|c|c|c|}
\hline Cell line & Genetic p53 status ${ }^{4}$ & p53 reporter activity $(\%)^{12}$ & Relative p53 protein level ${ }^{a}$ \\
\hline LN-18 & 238 Cys $\rightarrow$ Ser & $1(\mathrm{NS})^{\mathrm{b}}$ & 2.4 \\
\hline U138MG & $273 \mathrm{Arg} \rightarrow$ His heterozygous & 9 & 8.7 \\
\hline U87MG & Wild-type & 36 & 1.0 \\
\hline LN-428 & $173 \mathrm{Val} \rightarrow$ Met $282 \mathrm{Arg} \rightarrow \operatorname{Trp}$ & 0 & 11.0 \\
\hline D247MG & Wild-type & 77 & 3.6 \\
\hline T98G & $237 \mathrm{Met} \rightarrow$ Ile & 0 & 10.1 \\
\hline LN-319 & $175 \mathrm{Arg} \rightarrow \mathrm{His}$ & 1 (NS) & 12.7 \\
\hline LNT-229 & Wild-type & 100 & 6.0 \\
\hline A172 & Wild-type & 25 & 6.0 \\
\hline U251MG & $273 \mathrm{Arg} \rightarrow$ His homozygous & 0 & 9.6 \\
\hline U373MG & 273 Arg $\rightarrow$ His homozygous & 0 & 11.0 \\
\hline LN-308 & Deletion & 0 & 0 \\
\hline
\end{tabular}

${ }^{\text {aP }}$ rotein levels were calculated densitometrically. ${ }^{4} \mathrm{NS}$, not significantly different from experimentally determined background ${ }^{12}$

amenable to this kind of genetic engineering. Instead, small chaperone-like molecules that functionally restore mutationally destabilised p53 could exploit the accumulation of mutant p53 in cancer cells to trigger a massive antiproliferative or apoptotic response. Such effects were previously demonstrated in vitro and in vivo for CP-31398 and PRIMA-1., However, based on physico-chemical data, the interaction between CP-31398 and p53 has been questioned. ${ }^{20}$ The present study now characterises a novel p53 rescue compound, P53R3 (Figure 1a). The compound was originally identified using p53 DNA binding assays. It restores sequence-specific DNA binding to various p53 hot spot mutants, including $\mathrm{p} 53^{\mathrm{R} 175 \mathrm{H}}, \mathrm{p} 53^{\mathrm{R} 248 \mathrm{~W}}$ and $\mathrm{p} 53^{\mathrm{R} 273 \mathrm{H}}$ (Figure $1 b$ ) and enhances the recruitment of wild-type p53 and $\mathrm{p} 53^{\mathrm{M} 237 \mathrm{I}}$ to several target gene promoters (Figure 3 ).

Using the p53-deficient glioma cell line LN-308 as a model system, we demonstrate that P53R3 does not display p53-independent cytotoxicity towards $\mathrm{p} 53^{-1-}$ cells. Instead, low concentrations of P53R3 had a slight proliferative effect on LN-308 control transfectants, which was not observed with a p53-expressing cell line (data not shown). However, the plasmid-based overexpression of the mutants $p 53^{\mathrm{R} 175 \mathrm{H}}$, $p 53^{\mathrm{R} 248 \mathrm{~W}}$ and $\mathrm{p} 53^{\mathrm{R} 273 \mathrm{H}}$ potently sensitises the cells to P53R3-mediated proliferation inhibition (Figure $2 b$ and $c$ ). In contrast, PRIMA-1, which had originally been identified by its ability to trigger p53-dependent growth inhibition in cell lines bearing $\mathrm{p} 53^{\mathrm{R} 175 \mathrm{H}}, \mathrm{p} 53^{\mathrm{R} 273 \mathrm{H}}$ and other p53 mutants, ${ }^{2}$ did not exert p53-specific antiproliferative effects in this system. PRIMA-1, on the other hand, exerts p53-dependent cytotoxicity in the LN-308 model system when the DNA binding mutant $p 53^{R 273 H}$, but not when the $p 53^{R 248 W}$ or the $p 53^{R 175 H}$ mutant is present. Since PRIMA-1 had already been shown to refunctionalise $\mathrm{p}^{\mathrm{R}} \mathrm{R}^{\mathrm{R} 175 \mathrm{H}}$ in SKOV and $\mathrm{H} 1299$ cells, ${ }^{2}$ it appears to strongly depend on both the specific mutation and the cellular background whereas P53R3 seems to possess stronger p53-dependent antiproliferative properties and broader mutational specificities than PRIMA-1.

Transcriptional profiling experiments in T98G (p53 ${ }^{\mathrm{M} 237 \mathrm{I}}$ ) glioma cells confirmed that P53R3 induces 15 of 25 tested p53 target genes in a p53-dependent manner. Specificity was controlled by an RNAi-mediated knockdown of p53, which largely abrogated the observed effects (Figure $4 \mathrm{~b}$, upper panel). When the same experiment was repeated in LNT-229 p53 wild-type cells, the effects were weaker than in the p53 ${ }^{\mathrm{M} 237 \mathrm{I}}$ cells (Figure 4b, lower panel) and, again, susceptible to downregulation of $p 53$. The finding that P53R3 may also affect wild-type p53 in glioma cells to some extent is not surprising since tumour cells are likely to inhibit wild-type p53 function by other mechanisms such as overexpression of MDM-2, ${ }^{21} \Delta \mathrm{Np} 73^{22}$ or p53-associated, Parkin-like cytoplasmic protein (PARC). ${ }^{23}$ Considering that P53R3 did not affect non-neoplastic control cells even at high concentrations (Table 1), we presume that P53R3 may relieve the posttranslational suppression of endogenous p53 in tumour cells, but is unlikely to have severe p53-related side effects in healthy tissues. In fact, neurotoxicity, which must strictly be avoided during any glioblastoma treatment, appears rather unlikely with P53R3, given its predominantly cytostatic effects.

However, tumoricidal effects are clinically more attractive than mere antiproliferative properties. Since P53R3 also induces several proapoptotic p53 target genes (Figure 4b), we sought for a therapeutic role of P53R3 in potentiating cytotoxic antiglioma therapies. Given the impact of p53 status on tumour cell responses to radiotherapy or chemotherapy, ${ }^{24,25}$ a synergy between these standard therapies and P53R3 appears possible. A synergy with ultraviolet B-induced apoptosis has already been shown for CP- $31398^{26}$ whereas the compound did not increase the chemosensitivity of human melanoma cells to camptothecin, cisplatin or vincristine. ${ }^{27} \mathrm{~A}$ more novel candidate for a combined therapy with P53R3 is Apo2L.0. The proapoptotic Apo2L/TRAIL receptors, DR4 and DR5, are expressed on human glioma cell lines. ${ }^{28}$ Intratumoral application of His-tagged Apo2L effectively eradicated U87MG gliomas in nude mice in the absence of neurotoxicity. ${ }^{29}$ However, 9 of 12 glioma cell lines in the present study were resistant to Apo2L.0 when applied on its own. Smac agonists, which antagonise the antiapoptotic effector protein $\mathrm{XIAP}$, are one option to overcome Apo2L/TRAIL resistance in glioma cells in vivo. ${ }^{6}$ Since DR4 and DR5 are p53-inducible, ${ }^{7,8}$ p53 rescue compounds may enhance the surface expression of these receptors on neoplastic cells and thereby sensitise for Apo2L/TRAIL-induced apoptosis.

In the present study, we demonstrate that P53R3 induces DR5 mRNA, total protein and cell surface protein expression in human glioma cell lines mainly via transcriptional p53dependent mechanisms (Figures $4 \mathrm{~b}$ and $5 \mathrm{c}$ ), most likely by restoring the DNA-binding capacity of mutant p53 (Figures $1 \mathrm{~b}$ 

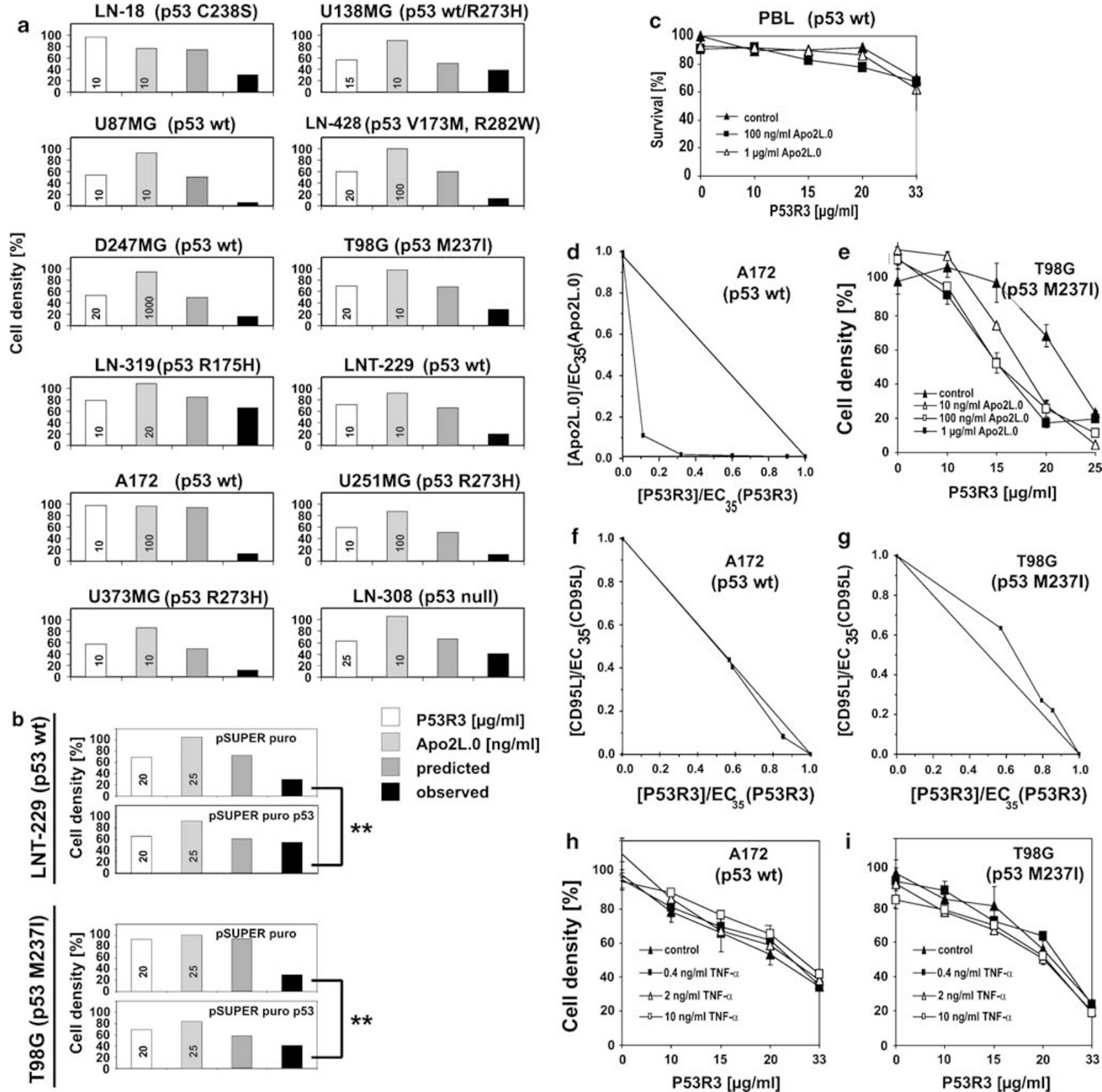

Figure 6 P53R3 sensitises human glioma cell lines to Ap02L.0-induced cell death. (a and $\mathbf{b})$ The cells were treated with the indicated concentrations of P53R3. After 24 $\mathrm{h}$, Apo2L. 0 was added for $16 \mathrm{~h}$ and cell survival was assessed by crystal violet staining. Selected data are displayed according to the fractional product method. ${ }^{13}$ The expected combined effects of P53R3 and Apo2L.0 in case of independent mechanisms of action are designated as 'predicted'. A synergy between P53R3 ( $\mu \mathrm{g} / \mathrm{ml}$ ) (open bars) and Apo2L.0 ( $\mathrm{ng} / \mathrm{ml}$ ) (light grey bars) was assumed when the 'observed' growth inhibition of the combined treatment (black bars) exceeded the 'predicted' growth inhibition (dark grey bars) by $>30 \%$. (a) Effects of P53R3 and Apo2L.0 on human glioma cell lines. (b) Effects of P53R3 and Apo2L.0 on T98G and LNT-229 pSUPERpurop53 and control cells. Significant differences in synergistic cell death induction are indicated by asterisks $\left({ }^{* *} P \leqslant 0.001\right.$, two-sided Student's $t$-test). (c) Human PBL were treated as in (a) and subjected to cell cycle analysis. Cells with a DNA content of $\geqslant 2 n$ were defined as viable. (d-i) A172 or T98G cells were pretreated with increasing concentrations of P53R3. After $24 \mathrm{~h}, \mathrm{Ap02L} .0$ ( $\mathbf{d}$ and $\mathbf{~ e ) , ~ C D 9 5 L ~ ( ~} \mathrm{f}$ and $\mathbf{g}$ ) or TNF- $\alpha$ ( $\mathrm{h}$ and i) were added for $16 \mathrm{~h}$ and cell survival was assessed by crystal violet staining. Results for the A172 cell line are displayed on the left $(\mathbf{d}, \mathbf{f}, \mathbf{h})$, data for T98G cells are shown on the right $(\mathbf{e}, \mathbf{g}, \mathbf{i})$. Where the toxicity of the death ligands alone was sufficient to allow isobologram analysis, data are displayed as isobolograms ${ }^{14}(\mathbf{d}, \mathbf{f}, \mathbf{g})$. Note that owing to the low cytotoxicity of the Apo2L.0 preparation used, $\mathrm{EC}_{35}$ values had to be employed for isobologram analysis instead of $\mathrm{EC}_{50}$ values. Where isobologram analysis was impossible, data are displayed as cell density curves for increasing concentrations of P53R3 in the presence or absence of the respective death ligand $(\mathbf{e}, \mathbf{h}, \mathbf{i})$. Data were normalised to a DMSO solvent control

and 3). Cellular expression of DR4, DcR1 and DcR2 remained largely unaffected by P53R3 (Table 2 and Figure 5a). The enhanced levels of DR5 at the cell surface were paralleled by a sensitisation to Apo2L.0-induced apoptosis (Figure 6), suggesting that DR5 upregulation may indeed play an important role in the mechanism of sensitisation. It is, 


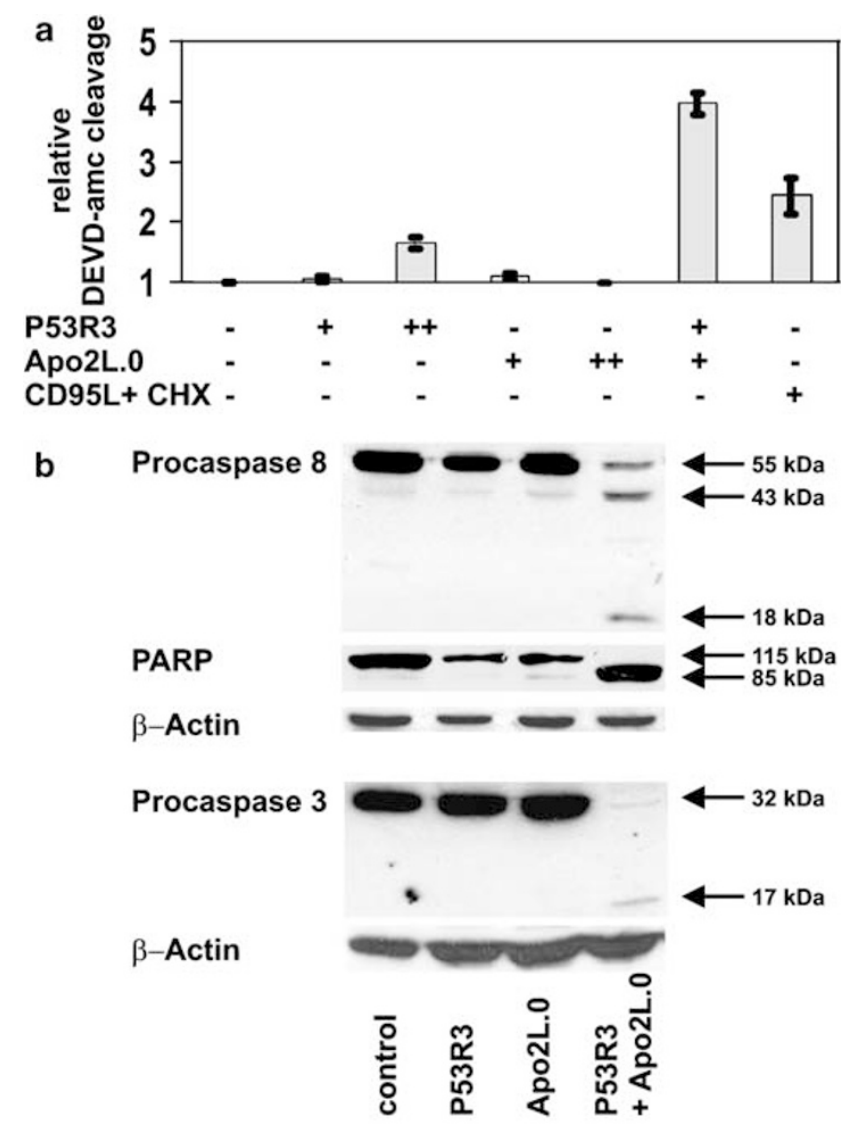

C

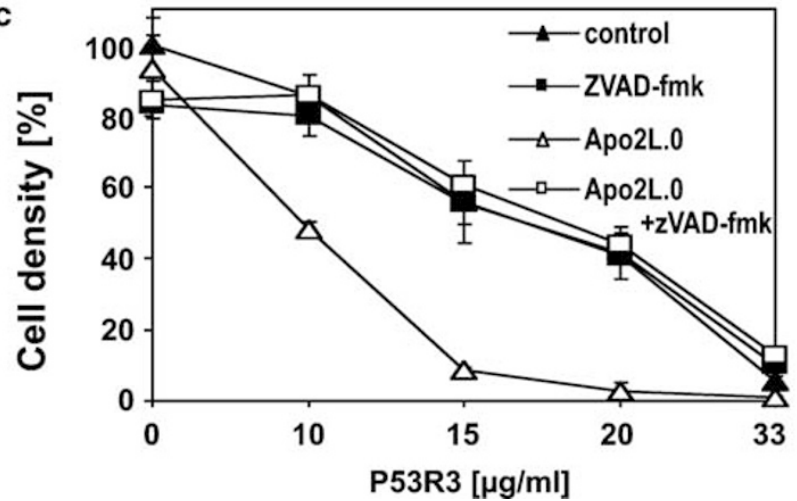

Figure 7 P53R3 sensitises for Apo2L.0-induced apoptosis upstream of caspase activation. (a) T98G cells $\left(2 \times 10^{4}\right.$ cells per well) were seeded in 96 well plates, adhered overnight and treated with $20 \mu \mathrm{g} / \mathrm{ml}(+)$ or $33 \mu \mathrm{g} / \mathrm{ml}(++)$ P53R3. At $24 \mathrm{~h}, 100 \mathrm{ng} / \mathrm{ml}(+)$ or $1 \mu \mathrm{g} / \mathrm{ml}(++)$ Apo2L.0 was added to some samples. Six hours later, DEVD-amc cleavage was assessed fluorometrically. As a positive control, T98G cells were treated with CD95L $(100 \mathrm{U} / \mathrm{ml})$ plus cycloheximide $(10 \mu \mathrm{g} / \mathrm{ml})$ for $4 \mathrm{~h}$. Data were normalised to the untreated control samples. (b) T98G cells were pretreated with P53R3 $(20 \mu \mathrm{g} / \mathrm{ml})$ for $24 \mathrm{~h}$ and co-treated with Apo2L.0 $(100 \mathrm{ng} / \mathrm{ml})$ for $6 \mathrm{~h}$, lysed and analysed for the processing of caspases 8 and 3 and PARP by immunoblot. (c) The cells were treated with increasing concentrations of P53R3 for $24 \mathrm{~h}$, followed by incubation with Apo2L.0 $(100 \mathrm{ng} / \mathrm{ml})$ in the presence or absence of ZVAD-fmk $(67 \mu \mathrm{M})$. Survival was assessed by crystal violet staining $16 \mathrm{~h}$ after addition of Apo2L.O. Data were normalised to a DMSO control

however, experimentally difficult to determine whether DR5 induction is critical for the observed synergy, since blocking of DR5 or siRNA-mediated downregulation of this death receptor confers general resistance towards Apo2L-induced cell death. $^{30}$ The synergy between P53R3 and Apo2L.0 involves the facilitated activation of caspases and is sensitive to the broad-range caspase inhibitor zVAD-fmk (Figure 7). The fact that the induction of DR5 observed in U138MG, LN-319 and LN-308 cells does not result in a strong sensitisation of these cell lines to Apo2L.0-induced apoptosis is most likely due to the presence of antiapoptotic mechanisms that are insensitive to p53. However, in consideration of the low intrinsic cytotoxic potency of the Apo2L.0 preparation used in this study, sensitisation in 9 of 12 glioma cell lines to this clinically apparently safe pro-apoptotic agent is still a promising result that warrants further exploration in an in vivo system.

The knockdown of endogenous p53 in p53 wild-type LNT229 cells and p53 mutant T98G cells desensitised the respective cells to the P53R3-mediated upregulation of DR5 and the combined cytotoxicity of P53R3 and Apo2L.0, confirming that p53-dependent effects strongly contribute to the synergy of P53R3 and Apo2L/TRAIL. No synergistic effects were observed in PBL (Figure 6c). Further, potential problems caused by P53R3-mediated sensitisation of normal somatic cells to the cytotoxic effects of Apo2L.0 could be circumvented by restricting the application of Apo2L.0 locally to the tumour at least in the context of gliomas. Therefore, we suggest that future in vivo experiments should combine systemic administration of P53R3-like agents with intratumoral application of Apo2L.0. This approach could combine low p53-independent cytotoxicity with P53R3-mediated systemic inhibition of tumour cell proliferation and high intratumoral cytotoxicity achieved by the synergy between P53R3 and Apo2L.0.

\section{Materials and Methods}

Materials and cell lines. A $10 \mathrm{mg} / \mathrm{ml}$ stock solution of P53R3 was prepared in DMSO. PRIMA-1 (Calbiochem, San Diego, CA, USA) was dissolved in PBS ( $2 \mathrm{mg} /$ $\mathrm{ml}$ ). Apo2L.0 was kindly provided by A Ashkenazi (San Francisco, CA, USA). CD95L-containing supernatant was harvested from CD95L-transfected N2A neuroblastoma cells. ${ }^{31}$ TNF- $\alpha$ was purchased from Peprotech (Rocky Hill, NJ, USA). DEVD-amc and ZVAD-fmk were obtained from Bachem (Heidelberg, Germany). Cycloheximide, propidium iodide (PI) and all other reagents, unless indicated otherwise, were purchased from Sigma (St Louis, MO, USA). The human malignant glioma cell line T98G was obtained from the American Type Culture Collection (Rockville, MD, USA). All other cell lines were kindly provided by Dr. N de Tribolet (Lausanne, Switzerland). Human fibroblasts were obtained from skin biopsies of healthy volunteers. HCT116 p53 ${ }^{\text {wt }}$ and HCT116 $p 53^{-/-}$cells were a generous gift from B Vogelstein (Baltimore, MD, USA). Cells were cultured in Dulbecco's modified Eagle's medium (DMEM) containing $10 \%$ fetal calf serum (FCS), $2 \mathrm{mM}$ glutamine and penicillin $(100 \mathrm{IU} / \mathrm{ml} / \mathrm{streptomycin}(100 \mu \mathrm{g} / \mathrm{ml})$. Cell density was assessed by crystal violet staining. For the determination of $\mathrm{EC}_{50}$ values, drug effects were monitored in serial dilutions $(1: 2)$ over a broad range of concentrations.

Cerebellar granule neurons from 7-day-old Sprague-Dawley rats were kindly supplied by JB Schulz (Tübingen, Germany). Drug effects on these cells were determined by Alamar Blue ${ }^{\mathrm{TM}}$ staining (Biosource International, Camarillo, CA, USA). Monocyte-depleted PBL from healthy volunteers were prepared by density gradient centrifugation (Biocoll, Biochrom KG, Berlin, Germany) and cultured in RPMI 1640 medium with $10 \%$ FCS. Viability was assessed by flow cytometric analysis of DNA content.

RNA interference for endogenous p53. A knockdown of endogenous p53 was achieved using the pSUPER plasmid, ${ }^{32}$ which was modified by the insertion of a puromycin resistance cassette (pSUPERpuro). The following 
oligonucleotides for the downregulation of p53 were annealed and cloned into the vector: GATCCCCGACTCCAGTGGTAATCTACTTCAAGAGAGTAGATTACCAC TGGAGTCTTTTTGGAAA $\left(5^{\prime} \rightarrow 3^{\prime}\right)$ and TCGATTTCCAAAAAGACTCCAGTG GTAATCTACTCTCTTGAAGTAGATTACCACTGGAGTCGGG $\quad\left(3^{\prime} \rightarrow 5^{\prime}\right) . \quad$ p53 knockdown and empty control plasmids were transfected into glioma cell lines to generate stable sublines.

Generation of stably transfected sublines. Glioma cell lines were transfected by lipofection using FuGene6 (Roche, Mannheim, Germany). The plasmids encoding mutant p53 (pCMV-neo-Bam-p53 ${ }^{\mathrm{R} 175 \mathrm{H}}$ and pCMV-neo-Bam$\mathrm{p} 53^{\mathrm{R} 273 \mathrm{H}}$ ) were kindly provided by B Vogelstein (Baltimore, MD, USA). At $48 \mathrm{~h}$ after transfection, the cells were shifted to medium supplemented with G418 sulphate $(1 \mathrm{mg} / \mathrm{ml})$ or puromycin $(2 \mu \mathrm{g} / \mathrm{ml})$. For all experiments, pooled transfectants rather than single clones were used.

DNA binding assays. Preparation of nuclear extracts and gel-shift DNA binding assay were performed as described. ${ }^{9}$

Chromatin immunoprecipitation. Chromatin immunoprecipitation was performed similarly as previously described. ${ }^{33}$ In brief, the cells from two $15 \mathrm{~cm}$ plates were harvested by trypsinisation and fixed in complete DMEM with $1 \%$ formaldehyde for $10 \mathrm{~min}$. Glycine was added to give $0.125 \mathrm{M}$ final concentration. Cells were washed twice with TBS and resuspended in $2 \mathrm{ml} \mathrm{SDS}$ buffer $(50 \mathrm{mM}$ Tris/ $\mathrm{HCl} \mathrm{pH} \mathrm{8.0,0.5 \%} \mathrm{SDS,} 100 \mathrm{mM} \mathrm{NaCl}, 5 \mathrm{mM}$ EDTA and protease inhibitors (complete mini, Roche)). Nuclei were pelleted and resuspended in $2 \mathrm{ml} \mathrm{IP} \mathrm{buffer}$ (67 mM Tris/ $/ \mathrm{HCl}, \mathrm{pH} 8.3,100 \mathrm{mM} \mathrm{NaCl}, 5 \mathrm{mM}$ EDTA, 0.33\% SDS, 1\% Triton X-100 and protease inhibitors). Chromatin was fragmented by sonication $(3 \times 30 \mathrm{~s}, 18 \%$ of total power) to a size of 200-500 bp using a Bandelin Sonopuls HD2070 sonifier and precleared by centrifugation and incubation with $10 \mu$ l Protein $\mathrm{G}$ sepharose (GE Healthcare) for $1 \mathrm{~h}$. Protein $\mathrm{G}$ sepharose was blocked with $1.5 \mathrm{mg} / \mathrm{ml}$ sonicated salmon sperm DNA (Biomol) for $1 \mathrm{~h}$ at $4^{\circ} \mathrm{C}$. ChIP was performed in the presence of $5 \mu \mathrm{g}$ anti-p53 (clone DO-1, Santa Cruz SC-126) or mouse IgG2a control antibody (M5407, Sigma) and $20 \mu \mathrm{l}$ blocked Protein $\mathrm{G}$ sepharose for $16 \mathrm{~h}$ at $4^{\circ} \mathrm{C}$. The immunoprecipitate was washed twice with IP buffer containing $500 \mathrm{mM} \mathrm{NaCl}$, once with IP buffer and finally with PBS. Bound DNA was extracted by Proteinase $\mathrm{K}$ digestion $\left(2 \mathrm{~h}, 42^{\circ} \mathrm{C}\right)$ and thermal de-crosslinking $\left(6 \mathrm{~h}, 65^{\circ} \mathrm{C}\right)$, followed by DNA purification (Qiagen PCR purification kit; Qiagen, Hilden, Germany). Eluted fragments were amplified by RT-PCR using the following primers (forward and reverse):

Chk1: 5'-AAGCTCCAACATAAACTGCTCGCTTTC-3', 5'-GTGCTTTGTAAA CCTCAGAGTGGGGTACT-3'; GADD45: 5'-GGATCTGTGGTAGGTGAGGGT CAGG-3', 5'-GGAATTAGTCACGGGAGGCAGTGCAG-3'; DR5: 5'-GATCTACTT TAAGGGCTGAAACCCACGG-3', 5'-GGCGACAACGAGCACAAGGGTCTTGGG3'; PUMA: 5'-GGAGGAAAGCTGAGGAGTTCCCAATGTTGC-3', 5'-CTTACTGGG TCTCACCCAATCGCAATCGCC-3'; miR-34a: 5'-CGCAGCGACTGAGAAACAC$3^{\prime}, 5^{\prime}$-CACGAGCAGGAAGGAGGAC-3'; p21: 5'-CCTTTGGATGGTTTGGATGTA3', 5'-GGGAGGACAGGCTTCTTTCT-3'; GAPDH: (control) 5'-TGGTATCGTG

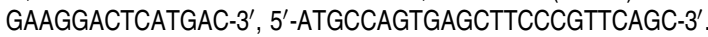

Proliferation assay. The cells were treated with P53R3 or PRIMA-1 as indicated for $16 \mathrm{~h}$ before they were pulsed for $8 \mathrm{~h}$ with [methyl- ${ }^{3} \mathrm{H}$ ] thymidine $(0.25 \mu \mathrm{Ci}$; Amersham, Braunschweig, Germany), lysed and harvested with a cell harvester (Inotech, Dottikon, Switzerland). Incorporated radioactivity was bound to a glass fibre filtermat (Wallac, Turku, Finland). The filtermat was wetted with Ultima Gold Scintillation Cocktail (Packard, Dreieich, Germany) and radioactivity was determined in a Wallac 1450 Microbeta Plus Liquid Scintillation Counter (Wallac).

Immunoblot analysis. The general procedure has been described. ${ }^{28}$ The cells were untreated or treated with P53R3 or Apo2L.0 or both as indicated and lysed. Soluble protein levels were analysed by immunoblotting using $20 \mu \mathrm{g}$ of protein per lane separated on 10-12\% acrylamide gels (Biorad, Munich, Germany). After transfer to a nitrocellulose membrane, the blots were pretreated for $1 \mathrm{~h}$ with PBS containing 5\% skim milk and $0.05 \%$ Tween 20 and then incubated overnight with the following antibodies: murine antihuman p53 monoclonal antibody Bp53-12 $(2 \mu \mathrm{g} / \mathrm{ml})$, goat antimammalian $\beta$-actin polyclonal antibody $\mathrm{l}-19(1 \mu \mathrm{g} / \mathrm{ml})$, rabbit anti-p21 (SC397), rabbit antimammalian caspase 8 polyclonal antibody p20 $(0.5 \mu \mathrm{g} /$ $\mathrm{ml}$ (all from Santa Cruz, CA, USA), mouse antihuman caspase 3 C31720 $(1 \mu \mathrm{g} / \mathrm{ml})$ and mouse antihuman-PARP 4C10-5 (BD Pharmingen, Heidelberg, Germany).
Visualisation of protein bands was accomplished using horseradish peroxidasecoupled IgG secondary antibody and enhanced chemoluminescence (Amersham).

Flow cytometry. For cell cycle analysis, glioma cells were treated with P53R3 or PRIMA-1 as indicated, harvested, fixed and permeabilised over night in ice-cold $70 \%$ ethanol (Merck, Darmstadt, Germany). The cells were washed twice with PBS. RNA was digested with RNase A (Gibco Life Technologies, Paisley, UK). The DNA was stained with PI $(50 \mu \mathrm{g} / \mathrm{ml})$. Fluorescence was recorded in a CyAn ADP S2536 analyser (Dako Cytomation, Carpinteria, CA, USA). Instrument settings were adjusted to move the $G_{0} / G_{1}$ peak to 200 relative fluorescence units. A total of 10000 events per condition was recorded. Data were evaluated using the ModFit Software (Verity, Topsham, ME, USA).

To analyse the cell surface expression of Apo2L/TRAIL receptors, CD95 or TNF receptor 1 (TNF-R1) (p55), the cells were incubated with or without $10 \mu \mathrm{g} / \mathrm{ml}$ P53R3 for $16 \mathrm{~h}$, harvested using Accutase (PAA, Vienna, Austria) and washed with PBS. The following steps were carried out at $4^{\circ} \mathrm{C}$ in flow cytometry buffer (PBS, $1 \%$ bovine serum albumin, $1 \% \mathrm{FCS}$ ). The cells were pretreated with $10 \%$ rabbit serum for $30 \mathrm{~min}$ and incubated for $1 \mathrm{~h}$ with $10 \mu \mathrm{g} / \mathrm{ml}$ mouse $\operatorname{lgG} 1 \kappa$ isotype control antibody or mouse antihuman DR4 clone 69036, DR5 clone 71908, DcR1 clone 90906, DcR2 clone 104918 (all R\&D Systems, Minneapolis, MN, USA), mouse antihuman TNF-R1 (p55) clone H398 (generously provided by Peter Scheurich, Stuttgart, Germany) or mouse antihuman CD95 clone M3 (American Type Culture Collection). After two further washing steps, $4 \mu \mathrm{g} / \mathrm{ml}$ biotinylated rabbit anti-mouse $\mathrm{F}\left(\mathrm{ab}^{\prime}\right)_{2}$ (Dako Cytomation) was added for $20 \mathrm{~min}$. Following two more washes, the cells were stained for $20 \mathrm{~min}$ in $2 \mu \mathrm{g} / \mathrm{ml}$ streptavidin-allophycocyanin (BD Pharmingen). Unbound staining reagent was removed by washing, PI $(50 \mu \mathrm{g} / \mathrm{ml})$ was added and Apo2L/TRAIL receptor expression was analysed using the CyAn ADP S2536 flow cytometer. PI-positive, that is dead cells were gated out. The median fluorescence intensities of the samples achieved with specific antibody were divided by those achieved with isotype control antibody to obtain specific fluorescence indexes. To analyse the total levels of DR5, the cells were fixed with $2 \%$ paraformaldehyde in PBS after harvesting, washed, heated in a microwave to the boiling point and cooled on ice for $10 \mathrm{~min}$. The ensuing procedure was carried out in flow cytometry buffer containing $0.1 \%$ (w/v) saponin to permeabilise the cells. After one wash, the cells were treated as the samples for the analysis of DR5 surface expression.

Real-time PCR. RNA was isolated using the RNeasy Mini Kit (Qiagen). SuperScript II RT (Gibco) was employed for cDNA synthesis. cDNA amplification was monitored using SYBRGreen chemistry (ABgene, Epsom, UK) on the ABI PRISM 7000 Sequence Detection System (Applied Biosystems, Weiterstadt, Germany). The conditions for all PCR reactions were as follows: 40 cycles of $95^{\circ} \mathrm{C}$ for $15 \mathrm{~s}$ and $60^{\circ} \mathrm{C}$ for $1 \mathrm{~min}$, using the following specific primers (forward and reverse): 18S: 5'-CGGCTACCACATCCAAGGAA-3', 5'-GCTGGAATTACCGCG GCT-3'; DR5: $5^{\prime}$-CCTGCTGGATGCCTTGGA-3', 5'-CCAGAGCTCAACAAGT GGTCCT-3'; Mdm2: 5'-CCCTGGTTAGACCAAAGCCAT-3', 5'-GGCACGCC AAACAAATCTCC-3'; p21: 5'-GGCGGCAGACCAGCATGACAGATT-3', 5'-GC AGGGGGCGGCCAGGGTAT-3'; miR-34a: 5'-CGTCACCTCTTAGGCTTGGA-3', 5'-CATTGGTGTCGTTGTGCTCT-3'; GADD45: 5'-CCATGCAGGAAGGAAA ACTATG-3', 5'-CCCAAACTATGGCTGCACACT-3'; WIP1: 5'-CTAAGGACCAT ATACCTGCCCT-3', 5'-TGACTACACCTTGGACATTCTCT-3'; Cyclin D1: $5^{\prime}$ GTGCTGCGAAGTGGAAACC-3', 5'-ATCCAGGTGGCGACGATCT-3'; Cyclin G: 5'-ATGACTGCAAGACTAAGGGACT-3', $\quad$ 5'-GTGCTTGGGCTGTACCTTCA-3'; TGF- $\alpha$ : $5^{\prime}$-GGCCCTGGCTGTCCTTATC-3', $5^{\prime}$-AGCAAGCGGTTCTTCCCTTC-3'; Chk1: 5'-CCAGATGCTCAGAGATTCTTCCA-3', 5'-TGTTCAACAAACGCTCAC GATTA-3'; p27: 5'-AACGTGCGAGTGTCTAACGG-3', 5'-CCCTCTAGGGG TTTGTGATTCT-3'; Bax: $5^{\prime}$-CCCGAGAGGTCTTTTTCCGAG-3', 5'-GGCGTC CCAAAGTAGGAGA-3'; CD95: $5^{\prime}$-TATCACCACTATTGCTGGAGTCA-3', $5^{\prime}-$ GCTGTGTCTTGGACATTGTCA-3'; CD95L: 5'-GAACTCCGAGAGTCTACCAGC3', 5'-TTGCCTGTTAAATGGGCCACT-3'; WIG-1: 5'-CCGTGCTTCCTCCACCT AAG-3', 5'-CTTCCCCTGCAAGAGGCAA-3'; GML: 5'-CCTCTTTGCCTTACTC CTAGCC-3', 5'-CGCACAGTCATGGCATCTCA-3'; P2XM: $\quad 5^{\prime}$-TTCCGTCACT CAGATCAAGGA-3', $\quad 5^{\prime}$-GGCGTCACAAGGAAGTTGGT-3'; PUMA: $5^{\prime}$-GACC TCAACGCACAGTACGAG-3', 5'-AGGAGTCCCATGATGAGATTGT-3'; Scotin: 5'-GTGGTGAGGTGTGTATGGCTT-3', 5' -GCACGTCAGAGCAGCAGTATT-3'; PERP: $5^{\prime}$-AGATGCTTGTCTTCCTGAGAGT-3', 5'-AGCAGGGTTGGCATGAAGG$3^{\prime} ;$ TSP-1: $\quad 5^{\prime}$-TGCCTGATGACAAGTTCCAAG-3', $\quad 5^{\prime}$-CCAGAGTGGTCTTTC CGCTC-3'; BAl1: $\quad 5^{\prime}$-CTACATCCGCTGTGTTTCCAT-3', 5'-TCTCTGTCA TGTTCCTCAGGAC-3'; TP53TG1: 5'-TCCCAGTGAGCCGCTTTTTG-3', 5'-CGG 
GGTGGACAATAAGATTCCT-3'; PIG-3: 5'-CCGGAAAACCTCTACGTGAAG-3', 5'-GCCTTGTCTCTGCATTAAGTCC-3'; PIG-6: 5'-AGCTGCTGTATGTTTCCAG GA-3', 5'-CCGCTTATTCGTGCCACTG-3'.

Relative induction levels (rl) of DR5 mRNA were calculated by the formula

$$
\begin{aligned}
\mathrm{rl}= & 2^{-[(\text {threshold cycle DR5-threshold cycle 18S) P53R3-treated cells }} \\
& - \text { (threshold cycle DR5-threshold cycle 18S) } \\
& \text { untreated cells }]
\end{aligned}
$$

DEVD-amc cleavage assay. The cells were seeded in 96 well plates, treated as indicated, lysed in $25 \mathrm{mM}$ Tris- $\mathrm{HCl}, \mathrm{pH}$ 8.0, $60 \mathrm{mM} \mathrm{NaCl}, 2.5 \mathrm{mM}$ EDTA $0.25 \%$ Nonidet-P40 for $10 \mathrm{~min}$ and DEVD-amc was added at $12.5 \mu \mathrm{M}$. Caspase activity was assessed by fluorescence using a Berthold Mithras fluorimete (Berthold Technologies, Karlsbad, Germany) at $355 \mathrm{~nm}$ excitation and $475 \mathrm{~nm}$ emission wavelengths.

Data analysis. Data are representative of experiments performed three times with similar results. Viability and proliferation studies were performed using triplicate wells. Significance was assessed by $t$-test $(P<0.05)$. Synergy of P53R3 and death ligands was evaluated using the fractional product method ${ }^{13}$ or isobologram analysis. ${ }^{14}$ The former defines the predicted additive inhibition of growth as the product of residual growth observed with either agent alone, which closely approximates the biological effect of two agents acting via completely independent mechanisms. If the observed growth inhibition of P53R3 plus death ligand exceeded this predicted growth inhibition by at least $30 \%$, we considered this to reflect synergy. Using the latter method, $\mathrm{EC}_{35}$ values for each agent alone, or in combination with a fixed concentration of the second agent, were established from the concentration-effect curves. The $\mathrm{EC}_{35}$ values of co-treatment were divided by the $\mathrm{EC}_{35}$ value of each compound in the absence of the other. In a graphica representation, the straight line connecting the $\mathrm{EC}_{35}$ values of the two agents when applied on their own corresponds to additivity or independent effects of both agents. Values below this line indicate synergy, values above reflect antagonism.

Acknowledgements. We thank $\mathrm{J}$ Rieger for advice on statistical analyses, $M$ Hermisson for the generation of T98G pSUPERpuro and pSUPERpuro p53 sublines, JB Schulz for providing rat cerebellar granule neurons, $S$ Altenbehrend for expert technical assistance (all Tübingen) and G Meister (München) for support. Further technical assistance was provided by M Ossadnik (Würzburg). This study was supported by the Jacqueline Seroussi Memorial Foundation for Cancer Research.

1. Foster BA, Coffey HA, Morin MJ, Rastinejad F. Pharmacological rescue of mutant p53 conformation and function. Science 1999; 286: 2507-2510.

2. Bykov VJ, Issaeva N, Shilov A, Hultcrantz M, Pugacheva E, Chumakov P et al. Restoration of the tumor suppressor function to mutant p53 by a low-molecular-weight compound Nat Med 2002; 8: 282-288.

3. Naumann U, Kügler S, Wolburg H, Wick W, Rascher G, Schulz JB et al. Chimeric tumor suppressor 1, a p53-derived chimeric tumor suppressor gene, kills p53 mutant and p53 wild-type glioma cells in synergy with irradiation and CD95 ligand. Cancer Res 2001; 61: 5833-5842.

4. Wischhusen J, Naumann U, Ohgaki H, Rastinejad F, Weller M. CP-31398, a novel p53stabilizing agent, induces p53-dependent and p53-independent glioma cell death. Oncogene 2003; 22: 8233-8245.

5. Rieger J, Naumann U, Glaser T, Ashkenazi A, Weller M. APO2 ligand: a novel lethat weapon against malignant glioma? FEBS Lett 1998; 427: 124-128.

6. Fulda S, Wick W, Weller M, Debatin KM. Smac agonists sensitize for Apo2L/TRAIL- or anticancer drug-induced apoptosis and induce regression of malignant glioma in vivo. Nat Med 2002; 8: 808-815.

7. Guan B, Yue P, Clayman GL, Sun SY. Evidence that the death receptor DR4 is a DNA damage-inducible, p53-regulated gene. J Cell Physiol 2001; 188: 98-105.
8. Wu GS, Burns TF, McDonald III ER, Jiang W, Meng R, Krantz ID et al. KILLER/DR5 is a DNA damage-inducible p53-regulated death receptor gene. Nat Genet 1997; 17: 141-143.

9. Demma MJ, Wong S, Maxwell E, Dasmahapatra B. CP-31398 restores DNA-binding activity to mutant p53 in vitro but does not affect p53 homologs p63 and p73. J Biol Chem 2004; 279: 45887-45896.

10. Sigal A, Rotter V. Oncogenic mutations of the $p 53$ tumor suppressor: the demons of the guardian of the genome. Cancer Res 2000; 60: 6788-6793.

11. Wischhusen J, Melino G, Weller M. p53 and its family members-reporter genes may not see the difference. Cell Death Differ 2004; 11: 1150-1152.

12. Schmidt F, Rieger J, Wischhusen J, Naumann U, Weller M. Glioma cell sensitivity to topotecan: the role of p53 and topotecan-induced DNA damage. Eur J Pharmacol 2001; 412. $21-25$

13. Webb JL. Effects of more than one inhibitor. In: Webb JL (ed). Enzyme and Metabolic Inhibitors: General Principles of Inhibition. Academic Press: New York, 1963, pp 487-512.

14. Berenbaum MC. Criteria for analyzing interactions between biologically active agents. Adv Cancer Res 1981; 35: 269-335.

15. Weller M, Frei K, Groscurth P, Krammer PH, Yonekawa Y, Fontana A. Anti-Fas/APO-1 antibody-mediated apoptosis of cultured human glioma cells. Induction and modulation of sensitivity by cytokines. J Clin Invest 1994; 94: 954-964.

16. Donehower LA, Harvey M, Slagle BL, McArthur MJ, Montgomery Jr CA, Butel JS et al. Mice deficient for p53 are developmentally normal but susceptible to spontaneous tumours. Nature 1992; 356: 215-221.

17. Xue W, Zender L, Miething C, Dickins RA, Hernando E, Krizhanovsky V et al. Senescence and tumour clearance is triggered by p53 restoration in murine liver carcinomas. Nature 2007; 445: 656-660.

18. Ventura A, Kirsch DG, McLaughlin ME, Tuveson DA, Grimm J, Lintault L et al. Restoration of p53 function leads to tumour regression in vivo. Nature 2007; 445: 661-665.

19. Martins CP, Brown-Swigart L, Evan Gl. Modeling the therapeutic efficacy of p53 restoration in tumors. Cell 2006; 127: 1323-1334.

20. Rippin TM, Bykov VJ, Freund SM, Selivanova G, Wiman KG, Fersht AR. Characterization of the p53-rescue drug CP-31398 in vitro and in living cells. Oncogene 2002; 21: 2119-2129.

21. Haupt $Y$, Maya $R$, Kazaz A, Oren M. Mdm2 promotes the rapid degradation of $p 53$. Nature 1997; 387: 296-299.

22. Müller M, Schilling T, Sayan AE, Kairat A, Lorenz K, Schulze-Bergkamen H et al. TAp73/ Delta Np73 influences apoptotic response, chemosensitivity and prognosis in hepatocellular carcinoma. Cell Death Differ 2005; 12: 1564-1577.

23. Nikolaev AY, Li M, Puskas N, Qin J, Gu W. Parc: a cytoplasmic anchor for p53. Cell 2003; 112: $29-40$

24. Weller M. Predicting response to cancer chemotherapy: the role of p53. Cell Tissue Res 1998; 292: 435-445.

25. Schmidt-Ullrich RK, Dent P, Grant S, Mikkelsen RB, Valerie K. Signal transduction and cellular radiation responses. Radiat $R$ es 2000; 153: 245-257.

26. Luu Y, Li G. The p53-stabilizing compound CP-31398 enhances ultraviolet-B-induced apoptosis in a human melanoma cell line MMRU. J Invest Dermatol 2002; 119: 1207-1209.

27. Luu Y, Li G. The p53-stabilizing compound, CP-31398, does not enhance chemosensitivity in human melanoma cells. Anticancer Res 2003; 23: 99-105

28. Röhn TA, Wagenknecht B, Roth W, Naumann U, Gulbins E, Krammer PH et al. CCNUdependent potentiation of TRAIL/Apo2L-induced apoptosis in human glioma cells is p53-independent but may involve enhanced cytochrome c release. Oncogene 2001; 20: $4128-4137$.

29. Roth W, Isenmann S, Naumann U, Kügler S, Bähr M, Dichgans J et al. Locoregional Apo2L/TRAIL eradicates intracranial human malignant glioma xenografts in athymic mice in the absence of neurotoxicity. Biochem Biophys Res Commun 1999; 265: 479-483.

30. Wang S, El-Deiry WS. Requirement of p53 targets in chemosensitization of colonic carcinoma to death ligand therapy. Proc Natl Acad Sci USA 2003; 100: 15095-15100.

31. Rensing-Ehl A, Frei K, Flury R, Matiba B, Mariani SM, Weller M et al. Local Fas/APO-1 (CD95) ligand-mediated tumor cell killing in vivo. Eur J Immunol 1995; 25: 2253-2258.

32. Brummelkamp TR, Bernards R, Agami R. A system for stable expression of short interfering RNAs in mammalian cells. Science 2002; 296: 550-553.

33. Tarasov V, Jung P, Verdoodt B, Lodygin D, Epanchintsev A, Menssen A et al. Differential regulation of microRNAs by p53 revealed by massively parallel sequencing: miR-34a is a p53 target that induces apoptosis and G1-arrest. Cell Cycle 2007; 6: 1586-1593. 